\title{
CRIMINALIZATION OF TERRORIST FINANCING: FROM THEORY TO PRACTICE
}

\author{
Hamed Tofangsaz*
}

This article analyzes the criminalization provisions of the International Convention for the Suppression of the Financing of Terrorism, the backbone of the legal regime for the prevention of terrorist financing. It makes a detailed examination of the background of the Convention and the nature of the negotiation discussions that led to its adoption. The drafters of the Convention were faced with two problems: first, how to define terrorism, terrorist acts, and terrorist groups, the financing of which should be addressed; second, the precise scope of the offense, in particular, how to define the preparatory acts of financing as an independent offense. This article argues that the definition of the offense provided by the Convention is far too ambiguous, and its application at national levels can often lead to an unjustifiable and unfair criminal law.

Keywords: terrorism, terrorist financing, criminalization, convention

*Hamed Tofangsaz is a Ph.D. candidate at the Faculty of Law, University of Waikato, New Zealand. He holds master's degrees in international relations (Azad University) and international commerce law (Macquarie University). His main research interests are in transnational criminal law and the comparative study of legal tools taken to suppress transnational crimes. His Ph.D. research focuses on the examination of counterterrorist financing measures. The author would like to express his special thanks to Professor Neil Boister for his enthusiastic guidance and insightful comments, and to the University of Waikato for its financial support. Also he would like to express his heartfelt gratitude to Dr. David and Mrs. Rosemary Troughton for their support and encouragement. The views expressed in this article are those of the author alone. The author can be contacted at: hamedtofangsaz@gmail.com.

New Criminal Law Review, Vol. 2I, Number I, pps 57-I40. ISSN 1933-4192, electronic ISSN I933-4206. (C) 20I8 by The Regents of the University of California. All rights reserved. Please direct all requests for permission to photocopy or reproduce article content through the University of California Press's Reprints and Permissions web page, http://www.ucpress.edu/ journals.php?p=reprints. DOI: https://doi.org/Io.I525/nclr.20I8.2I.I.57. 


\section{INTRODUCTION}

The creation of a comprehensive and international counterterrorism financing regime has been drawn from the idea that cutting off terrorist funds could slow down, disturb, and dismantle terrorist networks, which is similar to the ideas driving international measures against organized crime and money laundering. On a practical level, two international organizations-namely, the United Nations and the Financial Action Task Force (FATF) — created and perpetuate a system of measures to prohibit acts of financing, freeze terrorist funds, and track down terrorists. After the 9/II attacks, substantial efforts have been made to assure that countries have adopted and implemented laws consistent with these measures. However, it appears that these measures have been subject to relatively little critical scrutiny, and there has been little debate about whether these measures are proportionate to their potential effectiveness.

This article analyzes the criminalization provisions of the International Convention for the Suppression of the Financing of Terrorism, ${ }^{1}$ the backbone of the legal regime for the prevention of terrorist financing. It makes a detailed examination of the background of the Convention and the nature of the negotiation discussions that led to its adoption. The drafters of the Convention encountered two main problems: first, how to define terrorism, terrorist acts, terrorize purposes, and terrorist groups, the financing of which would be criminalized; second, the precise scope of the offense, in particular, how to define the preparatory acts of financing as an independent offense. This article argues that the definition of the offense provided by the Convention is far too ambiguous, and its application at national levels can often lead to an unjustifiable and unfair criminal law.

\section{A BRIEF HISTORY OF EFFORTS TO ADOPT A CONVENTION ON TERRORIST FINANCING}

It is hard to determine when and how the idea developed that drying up terrorist funds should become a central element in the fight against

I. United Nations, International Convention for the Suppression of the Financing of Terrorism, (Dec. 9, 1999) [hereinafter Terrorist Financing Convention], http://www.un. org/law/cod/finterr.htm. 
terrorism. ${ }^{2}$ But it seems that a call for the adoption of measures to counter terrorist financing was officially issued in $\mathrm{G} 7 / 8$ ministerial meetings, where it was agreed "to peruse measures aimed at depriving terrorists of their sources of finance." 3 Following the G8's statement of its interest in depriving terrorism of funding, in December 1996, the U.N. General Assembly adopted Resolution 51/210, establishing an ad hoc committee to "address means of further developing a comprehensive legal framework of conventions dealing with international terrorism." 4 Using identical wording to that used in the G7/8 Agreement, 25 Measures for Combating Terrorism, made in July 1996, the Resolution also called on all States to take steps to counteract terrorist financing. ${ }^{5}$

In the fall of 1998 , a draft of a convention on the suppression of the financing of terrorism, ${ }^{6}$ a French initiative at a G8 summit, ${ }^{7}$ was proposed

2. Michael Levi, Combating the financing of terrorism: a history and assessment of the control of "threat finance," 5o(4) Brit. J. Criminology 666 (20I0).

3. G7, Ottawa Ministerial Declaration on Countering Terrorism (Dec. I2, 1995), http:// www.g8.utoronto.ca/terrorism/terrorg6.htm. See also G7, Ministerial Conference on Terrorism, Agreement on 25 Measures (Paris, July 30, 1996), http://www.g8.utoronto.ca/ terrorism/terror25.htm. The role of G8 in the fight against terrorism is significant, as its members declared that "we are determined as a group to continue to provide leadership on this issue to the international community, using bilateral and multilateral measures and agreements to counter terrorism" (G7, 1995, id. at 9 I3). For more information about the role of the G8 in the fight against terrorism, see Andre Belelieu, The G8 and terrorism: What role can the G8 play in the 2Ist century?, G8 Governance (June 2002, No. 8), http://www. g8.utoronto.ca/governance/.

4. G.A. Res. 5I/210, ๆ 9, U.N. Doc. A/RES/5I/210 (Dec. I7, I996).

5. Compare I I9 of G7 Ministerial Conference (supra note 3) with 9 3(f) of G.A. Res. 5I/ 2IO, id. Both with the same wording called on all States to "take steps to prevent and counteract, through appropriate domestic measures, the financing of terrorists and terrorist organizations, whether such financing is direct or indirect through organizations which also have or claim to have charitable, social or cultural goals or which are also engaged in unlawful activities such as illicit arms trafficking, drug dealing and racketeering." The Resolution additionally emphasized the prevention of "the exploitation of persons for purposes of funding terrorist activities, and in particular to consider, where appropriate, adopting regulatory measures to prevent and counteract movements of funds suspected to be intended for terrorist purposes without impeding in any way the freedom of legitimate capital movements and to intensify the exchange of information concerning international movements of such funds."

6. Permanent Rep. of France to the U.N., Letter dated November 3, 1998 from the Permanent Rep. of France to the United Nations addressed to the Secretary-General, U.N. Doc. A/C.6/53/9 (Nov. 4, 1998).

7. G8, Foreign Ministers' Progress Report: Denver Summit of the Eight (Denver, June 2I, 1997), http://www.g8.utoronto.ca/summit/1997denver/formin.htm. For more details on the 
to the United Nations. By the requirement of the U.N. General Assembly, ${ }^{8}$ the draft was considered at a meeting of an ad hoc committee ${ }^{9}$ and then a Working Group of the Sixth Committee. ${ }^{10}$ After an evaluation, the Sixth Committee recommended that the General Assembly adopt the proposed convention. ${ }^{11}$ On December 9, 1999, the International Convention for the Suppression of the Financing of Terrorism (hereinafter, Terrorist Financing Convention) was adopted by the U.N. General Assembly and regarded as a significant contribution to the fight against terrorism. ${ }^{12}$

In general, the Convention followed the structure and standard provisions of its previous counterterrorism conventions, particularly the International Convention for the Suppression of Terrorist Bombing (hereinafter, Terrorist Bombing Convention). ${ }^{13}$ The notable example is Article 3 of the Terrorist Financing Convention, which limits its application to the cases involved with a transnational element. ${ }^{14}$ The Convention is also inapplicable to a situation involving armed conflict, because such situations are addressed by international humanitarian law. ${ }^{15}$ Similar to the Terrorist Bombing Convention, Articles 20 and 22 of the Convention emphasize

French initiative at the Denver summit, see Belelieu, supra note 3; Michele Fratianni, New perspectives on global governance: Why America needs the G8 (2005).

8. G.A. Res. 53/I08, ๆ I2, U.N. Doc. A/RES/53/Io8, (Jan. 26, I998).

9. Rep. of Ad Hoc Comm., 54th Sess., Dec. I7, 1966, U.N. Doc. A/54/37; GAOR, 54th Sess., Supp. No. 37 (1996).

Io. Rep. of Working Group, Measures to Eliminate International Terrorism, 6th Comm., 54th Sess., Oct. 26, 1999, U.N. Doc. A/C.6/54/L.2 (Oct. 26, 1999).

II. Josko Klisovic (Rapporteur of the Sixth Committee), Measures to Eliminate International Terrorism, U.N. Doc. A/54/615 (Nov. 30, 1999).

I2. U.N. GAOR, 54th Sess., 76th plen. Mtg at 3, U.N. Doc. A/54/PV.76 (Dec. 9, 1999).

I3. G.A. Res. 52/164, U.N. Doc. A/RES/52/164 (Jan. 9, 1997). For more details, see Clifton Johnson, Introductory note to the International Convention for the Suppression of the Financing of Terrorism, 39 InT'L Legal Materials 268, at 268 (2000).

I4. This is similar to Art. 3 of the International Convention Against the Taking of Hostages (New York, Dec. 17, 1979), https:/www.un.org/en/sc/ctc/docs/conventions/ Conv5.pdf; Art. 4(4) of the Convention for the Suppression of Unlawful Acts Against the Safety of Civil Aviation (Montreal, Sept, 23, 1971), http://www.un.org/en/sc/ctc/docs/ conventions/Conv3.pdf; and Art. 4 of the Convention for the Suppression of Unlawful Acts Against the Safety of Maritime Navigation (Rome, Mar. Io, 1988), http://www.un.org/en/ sc/ctc/docs/conventions/Conv8.pdf.

I5. Art. 2(b). This is identical to Art. I2 of the International Convention Against the Taking of Hostages and Art. I9 of the International Convention for the Suppression of Terrorist Bombing [hereinafter Terrorist Bombing Convention]. 
that it must be applied "in a manner consistent with the principles of sovereign equality and territorial integrity of States, and that of nonintervention in the domestic affairs of other States."16

The Convention provided a list of measures directed at terrorist financing, many of which were drawn from the 40 anti-money laundering recommendations of the Financial Action Task Force $\left(\mathrm{FATF}^{17}\right) .{ }^{18}$ It is not surprising that the United Nations, under the influence of $\mathrm{G} 7 / 8$, which conceived of the idea of counterterrorist financing, adopted such an approach early in the I990s, as it had continuously emphasized the possible link between terrorism and organized crime, particularly drug trafficking. ${ }^{19}$

The drafters were confronted with a difficult problem. To criminalize terrorist financing, they first had to overcome the lack of consensus on the definition of "terrorism." Creating the nature and defining the scope of new offense were the main and unusual problems that confronted the drafters. ${ }^{20}$

\section{THE PECULIARITIES OF THE NATURE OF THE CONCEPT OF TERRORISM ${ }^{21}$}

Logically, without defining "terrorism," "terrorist offenses," or "terrorist groups," it is impossible to address terrorist financing. Nonetheless, some peculiarities about the nature of terrorism have made not only all attempts to reach an agreement on the definition of "terrorism," until now, impossible, but also the criminalization of terrorist financing controversial. That is, there is no agreement on what types of conduct, in what circumstances

\footnotetext{
I6. This is similar to Articles I7 and I8 of the Terrorist Bombing Convention.

I7. The FATF is an intergovernmental body established by the G7/8 in 1989 to counter money laundering.

I8. Johnson, supra note I3, at 269.

19. See, e.g., G.A. Res. 49/6o U.N. Doc. A/RES/49/6o (Dec. 9, I994). Or see G.A. Res. 157/23, U.N. Doc. A/CONF 157/23 (July I2, 1993). Or see Ad Hoc Comm. on the Elaboration of a Convention against Transnational Organized Crime, Rep. on its $2 \mathrm{~d}$ sess., Feb. Io, 1999. U.N. Doc. A/AC 254/4 Rev. I (Mar. 8-I2, 1999).

20. Anthony Aust, Counter-terrorism-A new approach: The International Convention for the Suppression of the Financing of Terrorism, in 5 Max Plank Yearbook of United Nations Law 285, 286 (A. von Bogdandy \& R. Wolfrum eds., 200I), http://www.mpil.de/ files/pdfi/mpunyb_aust_5.pdf.

2I. Discussions in this part have been separately and independently addressed and published in the Journal of Financial Crime. See Hamed Tofangsaz, Terrorism or not terrorism? Whose money are we looking for?, 22(3) J. FIN. CRIME (20I5).
} 
and when, against whom (targets or victims), and with what intention or motivation constitute terrorism.

In terms of the objective element, the actus reus of the offense of terrorism is defined by scholars as the "underlying act," which is an offense in itself: murder, hijacking, kidnapping, and so on. ${ }^{22}$ The less discussed question is whether the underlying act of terrorism encompasses any unlawful conduct, including violence, "repressive acts," 23 and even minor criminal conduct like vandalism? Although some believe that the underlying acts of terrorism need only include serious offenses or "violence," 24 in providing a generic definition of "terrorism," some regional agreements include "any act which is a violation of the criminal laws of a State Party." 25 This seems to cover all criminal conducts. A U.N. draft Convention against Terrorism enumerates the underlying act of causing "death or serious bodily injury..., serious damage to public or private property ... resulting or likely to result in major economic loss." ${ }^{26}$ The question can be also raised whether lawful conduct that may terrorize people can be an underlying act.

The most peculiar feature of terrorism, as the famous dictum "one man's terrorist is another man's freedom fighter" indicates, is that "the same kind of action... will be described differently by different observers, depending on when and where it took place and whose side the observer is on." ${ }^{27}$ That is, terrorism, unlike other transnational crimes, is not inherently and always recognized as criminal. Its criminality can be circumstantial. There are some

22. Robert Cryer, An Introduction to international criminal law and procedure 289 (2d ed., 20IO). Ben Saul, Defining terrorism in international law, in OXFORD Monographs in International LaW 59 (2006).

23. Proposed by the Non-Aligned Group of $A d$ Hoc Committee (U.N. Doc. A/RES/ 3034(XXVII) (Dec. I8, I972)), reprinted in M. Cherif Bassiouni \& International Institute for Advanced Criminal Science, International terrorism and politICAL CRIMES 564 (I974).

24. Special Rapporteur on the promotion and protection of human rights and fundamental freedoms while countering terrorism, Report on Mission to Spain, \ 6, U.N. Doc. A/HRC/Io/3 Add.2 (Dec. I6, 2008). See also Cryer, supra note 22, at 289.

25. Art. I(3) of Organization of African Unity, OAU Convention on the Prevention and Combating of Terrorism (June 14, 1999). See also Art. I(2) of League of Arab States, Arab Convention on the Suppression of Terrorism (Cairo, Apr. 22, 1998); Art. I(2) of Organization of the Islamic Conference, Convention of the Organisation of the Islamic Conference on Combating International Terrorism (July I, 1999).

26. Draft Comprehensive Convention against International Terrorism, Art. 2, U.N. Doc. A/59/894 (Aug. I2, 2005).

27. Jenny Teichman, Terrorism, in Terrorism 5 (C.A. Gearty ed., I996). 
circumstances—-such as struggles for self-determination, attempts at national liberation, rebellion, and duress or necessity—on which there is no agreement whether terrorist-type conduct or the use of violence are unlawful and unjustifiable but excusable, or unlawful but justifiable, or even lawful. ${ }^{28}$ Although these circumstances might be regarded as exceptional, ambivalence about the use of terrorism in these circumstances has plagued agreement on a generic definition of "terrorism." 29 In some regional agreements, however, some of these circumstances have been taken into account by being exempted from the definition of "terrorism." ${ }^{30}$ Nonetheless, what law should govern such exempted acts, ${ }^{31}$ or whether these acts ought to be covered by the international humanitarian law or the "law of international criminal defences" has not been clarified either regionally or internationally. ${ }^{32}$

To solve the problem of how to label terrorist-type conduct, especially in those exceptional circumstances named, one may assume that specifying the targets or victims of terrorism can help to identify which acts constitute terrorism. But the peculiarity of terrorism also confuses the recognition of the targets of terrorism. Terrorism is a "compound offense" that needs both a mens rea in regard to its underlying act and a special intent in regard to the terrorism itself. So there are two types of victims: the victim of the underlying act and the "real target" at which the underlying act has been aimed. ${ }^{33}$

28. See the debates in U.N. Ad Hoc Committee Report (1937), U.N. Doc. A/9028; or U.N. Ad Hoc Committee Report (1977), U.N. Doc. A/34/39. See also Antonio Cassese, Self-determination of peoples: a legal reappraisal Hersch Lauterpacht memoRial lectures i52 (1996); M. Cherif Bassiouni \& International Institute for Advanced Criminal Science, International terrorism and political Crimes (1975); Georges Sorel, Reflections on violence (i96i); Ted Honderich, After the Terror I5I, I70, I84-85 (2003).

29. Neil Boister, An introduction to transnational criminal law 63 (20i2). 30. Art. 3(I) of Organization of African Unity, OAU Convention on the Prevention and Combating of Terrorism, exempts "the struggle waged by peoples ... for their liberation or self-determination, including armed struggle against colonalism, occupation, aggression and dominion by foreign forces" from being labelled as terrorst acts. See also Art. 2(a) of League of Arab States, Arab Convention on the Suppression of Terrorism; Art. 2(a) of Organization of the Islamic Conference, Convention of the Organisation of the Islamic Conference on Combating International Terrorism.

3r. For more details about the countries' positions on this issue, see Antonio CASSese, INTERNATIONAL CRIMINAL LAW I67, I68 (2d ed. 2008).

32. Saul, supra note 22, at I28.

33. Cryer, supra note 22, at 290. 
With regard to the targets of the underlying offense, there is a critical controversy about whether acts against non-human targets can be labelled as terrorism. A "British-inspired definition of terrorism" 34 includes various forms of damage to property and interference with or disruption of essential utilities and infrastructure. ${ }^{35}$ Others restrict this definition by requiring that such property damage be "likely to endanger human life." 36 In some regional agreements, an act falls within the scope of terrorism if it is committed with the intention of destabilizing or destroying "the fundamental political, constitutional, economic or social structure of a country or an international organization." 37 Although the property damage element is included in the U.N. Draft Convention definition of "terrorist acts," 38 it is neither in the list of the acts drawn by Resolution 1566 of the Security Council on the condemnation of terrorism, ${ }^{39}$ nor consistent with the meaning of "terrorism" advocated by the Special Rapporteur on the promotion and protection of human rights and fundamental freedoms while countering terrorism. ${ }^{40}$ The concern is expressed that whereas such inclusion can capture conduct of a terrorist nature, it is likely also to capture "conduct with no bearing at all to terrorism." ${ }^{\prime 1}$ A protest against the World Trade Organization, for instance, would be a terrorist act if it resulted in property damage. ${ }^{42}$

34. Kent Roach, The case for defining terrorism with restraint and without reference to political or religious motive, in LAW AND LIBERTY IN THE WAR ON TERROR 252, 40 (Andrew Lynch, Edwina MacDonald, \& George Williams eds., 2007).

35. See, e.g., Terrorism Act, 2000, § I(2)(b),(e) (U.K.), or Criminal Code Act, 1995, § Ioo. I(2)(b) (Austl.).

36. Terrorism Suppression Act, 2002, § 5(3)(d) (N.Z.).

37. Art. I(I) of EU Council, Framework on Combating Terrorism, (2002/475/JHA). See also Art. I(2) of Convention of the Organisation of the Islamic Conference on Combating International Terrorism.

38. Art. 2(b), (c) of U.N., Draft Comprehensive Convention against International Terrorism, U.N. Doc. A/59/894 (Aug. I2, 2005).

39. S.C. Res. 9 3, I566, U.N. Doc S/RES/1566 (2004). The Resolution defines terrorism as "criminal acts, including against civilians, committed with the intent to cause death or serious bodily injury, or taking of hostages, with the purpose to provoke a state of terror in the general public or in a group of persons or particular persons, intimidate a population or compel a government or an international organization to do or to abstain from doing any act."

40. Martin Scheinin, Report of the Special Rapporteur on the promotion and protection of human rights and fundamental freedoms while countering terrorism; promotion and protection of human rights, ๆฯ 36, 38, U.N. Doc. E/CN.4/2006/98 (Dec. 28, 2005).

4I. Id.

42. Cryer, supra note 22, at $29 \mathrm{I}$. 
With regard to the special intent of terrorism, the League of Nations in a failed attempt regarded terrorism as a criminal act with the intention of creating "a state of terror in the minds of particular persons, or a group of persons or the general public." ${ }^{43}$ In this definition, it is not clear whether intimidation is the primary purpose of the terrorists or whether it is a means for an ulterior end. A number of recent definitions broaden the element by requiring that the purpose of an act of terrorism must be "to intimidate a population, or to compel a government or an international organization to do or to abstain from doing any act." ${ }^{44}$ The difficulty is that it is not clear what degree of intimidation or compulsion must to occur for an act to be considered terrorism: $:^{45}$ mere intimidation ${ }^{46}$ or serious intimidation ${ }^{47}$ In addition, the concern has been expressed that none of these elements are easy to prove because terrorists do not necessarily issue specific demands or make openly public the purpose of their action. ${ }^{48}$ In the Boston marathon bombings, for example, it has not been plainly announced what the perpetrators intended to prompt the U.S. government to do or abstain from doing.

What complicates defining the subjective element of terrorism is the question of whether intimidation of the public or coercion of a State constitutes terrorism if it is motivated by personal impulses or by material gain such as in blackmail, extortion, revenge, or personal hatred. Although some propose that even acts of violence for personal gain should constitute terrorism, ${ }^{49}$ others exclude any terrorist-type conduct with

43. Art. I(2) of League of Nations, Convention for the Prevention and Punishment of Terrorism, C.546.M383.1937.v. (Nov. 16, 1937), ratified only by one State (India).

44. Art. 2(I)(b) of the Terrorist Financing Convention, supra note I.

45. Saul, supra note 22, at 6o.

46. Section $\mathrm{I}(\mathrm{b})$ of Terrorism Act 2000 (UK) considers an act as terrorism if it merely influences a government or an international organization.

47. Art. I(I) of EU Council, Framework on Combating Terrorism, considers as terrorism an act that aims to seriously intimidate a population, or unduly compel a government or international organization or seriously destabilize or destroy "the fundamental political, constitutional, economic or social structure of a country or an international organization." "Terrorism," in Section 89a of German Criminal Code, is defined as a "serious violent act endangering the state."

48. Geoffrey Levitt, Is terrorism worth defining?, OHIO N.U. L. Rev. 97, III (1986).

49. Non-Aligned Group's proposed definition of acts of terrorism includes "[a]cts of violence committed by individuals or groups of individuals for private gain, the effect of which are not confined to one state." See U.N. Doc. A/RES/3034(XXVII) reprinted in Bassiouni, supra note 23, at 564 . 
a private motive from a definition of terrorism. ${ }^{50}$ They argue that "if a definition of terrorism is to reflect the real nature of the harm that terrorism inflicts on the political process," public motives, including political, ideological, religious, ethnic, or philosophical motives, must be distinguished from "private violence." 51 It is exemplified that setting fire to a building motivated by nonpolitical, nonreligious, or nonideological desires cannot be regarded as terrorism, but as arson because a public motive is lacking. ${ }^{52}$ Similarly, an aggravated bank robbery may end with the killing or hostage taking, but if the bandits do that to facilitate fleeing unharmed, the intimidating of the public and coercing the police not to take any action against the bandits cannot be regarded terrorism because this action was not done for advancing an ideological, political, or other public cause. (There are, of course, a range of common crimes suited to deal with such situations. $)^{53}$

From a criminal law perspective, although motive is irrelevant to criminal culpability, it is again controversial whether the existing criminal law should be expanded to include motive as an element of the crime of terrorism. The proponents of such inclusion believe that requiring motive as a mental element "allows the criminal law to more finely target, stigmatise and deter what is considered by society to be especially wrongful about terrorism ... which is not inherent in a physical act of violence alone." 54 This may also help "satisfy public indignation, better express community condemnation," "placate popular (but reasonable) demands for justice," and "send[s] a symbolic message that certain kinds of violence cannot be tolerated in plural, secular democracies." 55

On the other hand, those who oppose defining the offense around the motive of the offender insist on retaining as many of the principles of criminal law as possible, including the general requirement for the proof of fault. ${ }^{56}$ Criticizing the inclusion of the motive requirement imposed by

50. Cassese, supra note 31, at I69.

5I. Saul, supra note 22, at 6I.

52. Cassese, supra note 3I, at I68.

53. $I d$.

54. Ben Saul, The curious element of motive in definition of terrorism: essential ingredient or criminalizing thought?, in LAW AND LIBERTY IN THE WAR ON TERROR 252, 29, 3 O (Andrew Lynch, Edwina MacDonald, \& George Williams eds., 2007).

55. Id., at 37 .

56. Roach, supra note 34 , at 42. 
some States, ${ }^{57}$ they correctly argue that motive should not excuse terrorism nor constitute part of the crime of terrorism because such inclusion would result in detrimental consequences: infringement of basic human rights such as freedoms of conscience, belief, religion, thought, expression, and association by targeting and prosecuting on political, religious, or ideological grounds $;{ }^{58}$ arousing and disseminating "suspicion and anger" of anyone who seems to belong to a religious, ideological, or political group connected to a terrorist act; 59 and "politicizing the investigative and trial process" by requiring intelligence agencies and trials to provide extensive evidence about the true meaning of a motive by which a terrorist act might be induced. ${ }^{60}$ Alternatively, they believe that a definition of "terrorism" will be less controversial and more acceptable if it relies more on the essence of terrorism, "namely the intentional murder and maiming of innocent civilians," rather than on motive. It is, therefore, thought preferable to concentrate on the physical harm caused by terrorist acts and to treat terrorists as ordinary criminals. As a solution, this seems deficient as it is not clear what, after all, is the definition of "innocent civilians" in peacetime or wartime? It is argued by some that the use of violence against non-innocent civilians is justified, in what is so-called "terrorism for humanity." 61

57. Section I(I)(c) of Terrorism Act 2000 (U.K.) defines terrorism as "the use or threat of action made for the purpose of advancing a political, religious, racial or ideological cause." See also § 83.I(I) of Criminal Code 1985 (Can.); $\$ 5$ of Terrorism Suppression Act 2002 (N.Z.); § I(I)(xxv)(c) of Protection of Constitutional Democracy Against Terrorist and Related Activities Act 2004 (S. Afr.); § IOo.I of Criminal Code Act 1995 (Austl.).

58. R v. Khawaja (2006) 2I4 C.C.C. (3d) 399, (Ontario Superior Court of Justice) \ฯ 45, 80 , and 73 .

59. Id. ๆ 58.

6o. Irwin Cotler, Terrorism, security and rights: The dilemma of democracies, in BETWEEN crime and war: Terrorism, democracy and the constitution 35-36 (Errol P. Mendes \& Debra M. McAllister, eds., 2002).

6i. Ted Honderich \& ebrary Inc., After the terror i5i, I70, I84-85 (rev. ed., 2003). See also Ted Honderich, Terrorism for humanity: Inquiries in political Philosophy (2003). The example of terrorism for humanity is Palestinian suicide attacks against Israelis, which is considered as the means for redeeming the Palestinians from Israel's domination. Honderich compares and analogizes Palestinian action with the intentional atomic bombing of innocents in the Second World War by the United States. 


\section{A. The Terrorist Financing Convention and the Definition of Terrorism}

The impossibility of reaching an agreement on a generic and authoritative definition of terrorism led initially to the adoption of a thematic approach to condemn and suppress terrorist acts. ${ }^{62}$ Accordingly, international conventions were negotiated on certain classes of offenses implicitly regarded as "terrorist," without attempting to define or even apply the term "terrorism" or imposing a special intent or motivation. ${ }^{63}$ Although setting aside the intent element in the favor of "sharply narrowed and highly elaborated" material elements made the inclusion of these sectoral conventions possible, ${ }^{64}$ the criticism has been expressed that the acts criminalized by the conventions miss the unique characteristic of terrorism as these agreements implicitly include acts committed for personal and material causes. ${ }^{65}$

Unlike the sectoral conventions, the drafters of the Terrorist Financing Convention could not define the new offense simply by reference to a particular type of act; ${ }^{66}$ rather, they would need to define "terrorism," the financing of which the Convention was going to criminalize. So the Convention adopted a twofold approach, ${ }^{67}$ a listing of offenses and "a

62. Cryer, supra note 22, at 285 .

63. These conventions are: Convention for the Suppression of Unlawful Seizure of Aircraft (The Hague, Dec. 1970); Convention for the Suppression of Unlawful Acts against the Safety of Civil Aviation (Montreal, Sept. 23, I97I); Convention on the Prevention and Punishment of Crimes against Internationally Protected Persons, including Diplomatic Agents (adopted by the U.N. General Assembly, Dec. I4, 1973); International Convention against the Taking of Hostages (adopted by the U.N. General Assembly, Dec. 17, 1979); Convention on the Physical Protection of Nuclear Material (Vienna, Mar. 3, 1980); Protocol for the Suppression of Unlawful Acts of Violence at Airports Serving International Civil Aviation, supplementary to the Convention for the Suppression of Unlawful Acts against the Safety of Civil Aviation (Montreal, Feb. 24, 1988); Convention for the Suppression of Unlawful Acts against the Safety of Maritime Navigation (Rome, Mar. Io, 1988); Protocol for the Suppression of Unlawful Acts against the Safety of Fixed Platforms located on the Continental Shelf (Rome, Mar. I0, 1988); International Convention for the Suppression of Terrorist Bombing (adopted by the U.N. General Assembly, Dec. 15, 1997); International Convention for the Suppression of Acts of Nuclear Terrorism New York (adopted by the U.

N. General Assembly, Apr. I3, 2005).

64. Levitt, supra note 48 , at IOI.

65. Cryer, supra note 22.

66. Aust, supra note 20, at 291.

67. U.N. Doc. A/C.6/54/L.2, supra note Io, Annex III, ๆ 62. 
mini-definition of terrorism." ${ }^{\text {" }} 8$ With regard to the former, the Convention prohibits the financing both of those acts within the scope of the sectoral conventions and of any further acts. ${ }^{69}$ With regard to the latter, it was also argued that it was necessary to include a generic definition of "terrorism" for the purpose of the Convention since "not all terrorist offences were covered" by the sectoral conventions. ${ }^{70}$ Despite little pressure to delete the mini-definition, ${ }^{71}$ the Convention defined terrorism as an

act intended to cause death or serious bodily injury to a civilian, or to any other person not taking an active part in the hostilities in a situation of armed conflict, when the purpose of such act, by its nature or context, is to intimidate a population, or to compel a government or an international organization to do or to abstain from doing any act. ${ }^{72}$

Although this definition was endorsed for the purpose of the Convention and for defining a new offense of terrorist financing, ${ }^{73}$ not all aspects of terrorism are clearly and comprehensively reflected in the definition, nor have all those international concerns discussed above been properly addressed. First of all, the Convention does not clarify whether, to be considered terrorism, the use of violence should be only against people as the generic definition indicates, or whether an act against property can be terroristic as inferred from the Convention's reference to the sectoral conventions, some of which criminalize acts against property. ${ }^{74}$

The Convention's identification of people as the victims of terrorism is also not compelling since it has been couched in vague terms. Unlike the first draft of the Convention, which did not even employ the term "armed conflict" on the grounds that the activities of armed forces during an armed conflict are understood under international humanitarian law, ${ }^{75}$ in a revised

68. Aust, supra note 20, at $29 \mathrm{I}$.

69. Terrorist Financing Convention, supra note I, Art. 2(I)(a).

70. Permanent Rep. of France to the U.N., supra note 9, Annex IV, 9 23. Also see U.N. Doc. A/C.6/54/L.2, supra note Io, Annex III, ๆ 6.

7I. U.N. Doc. A/C.6/54/L.2, supra note Io, Annex III, ๆ 8I.

72. Terrorist Financing Convention, supra note I, Art. 2(I)(b).

73. Aust, supra note 20, at 298.

74. For example, Art. II(I)(b) of Protocol for the Suppression of Unlawful Acts of Violence at Airports Serving International Civil Aviation covers acts which "destroy[s] or seriously damage $[s]$ the facilities of an airport serving international civil aviation or aircraft not in service located thereon or disrupts the services of the airport."

75. Permanent Rep. of France to the U.N., supra note 6, Art. 2I(2). 
version of the draft Convention, a provision was added to the definition of terrorism, prohibiting "[a]n act designed to cause death or serious bodily injury to a civilian or to any other person, other than in armed conflict...."76 The retention of the added provision was supported on the understanding that it was necessary for the Convention to cover not only civilians but also those who are not civilians "but were not engaged in armed conflict either," such as "off-duty military officers."77 However, the comment was made that the added provision implied that "civilians did not take part in hostilities, which was considered not to be always the case."78 Instead, it was proposed that the provision be amended to protect any person, whether civilian or nor, who is not "taking an active part" in hostilities. Although this proposal was not taken into account in reformulating the final draft, the qualifier "not taking an active part" was inserted in the definition of "terrorism" to include "any act intended to cause death or serious bodily injury to a civilian, or to any other person not taking an active part in the hostilities in a situation of armed conflict" within the scope of terrorism.

Such a reference to armed conflict can be problematic for the following reasons. Generally speaking, while the lack of consensus on the legitimacy or illegitimacy of the use of violence in some circumstances of armed conflict, such as self-determination or national movements, is one of the main obstacles to reaching a universal agreement on a definition of terrorism, the Convention evades the issue. This evasion increases "a possibility of legal dispute when the [Convention] is applied to a real case" 79 because some may insist on excluding the use of violence in those circumstances from being labelled as "terrorism." 80

In addition, it is not clear what the phrase "any other person not taking an active part in the hostilities in a situation of armed conflict" excludes from the definition. This could "give rise to disputes of interpretation, i.e., as to whether a particular act constituted terrorism, or was undertaken during armed conflict." The United States, for example, interprets this phrase to include an assault on off-duty military personnel in time of armed

76. U.N. Doc. A/AC.252/L.7 and Corr.I, reproduced in U.N. Doc. A/54/37, supra note 9, Annex II, Art. 2(I)(b).

77. U.N. Doc. A/C.6/54/L.2, supra note Io, Annex III, ๆ 102.

78. Id. 9 IOI.

79. Jae-myong KoH, Suppressing terrorist finanCing ANd MONEy LaUndering 65 (2006).

8o. U.N. Doc. A/C.6/54/L.2, supra note Io, supra note Io, ๆ 2. 
conflict. ${ }^{81}$ In this regard, whether to deal with combatants of various kinds as terrorists or as combatants might be controversial.

It is also significant to note that the Convention is silent on the definition of "civilian." So there remains a lot of controversy over the questions of whether Israeli settlers in Palestinian-occupied lands, Pied-noirs in Algeria, or white South Africans in the time of apartheid are or were, for instance, "innocent civilians," and whether the use of violence against police officers or government officials who implement the oppressive policies of a government constitute terrorism. ${ }^{82}$

The attempt of the authors of the Convention to specify the intention or purpose of the crime is also subject to criticism for its breadth. According to the definition, it may suffice for an act to be classified terroristic if it is determined that the purpose of the act, "by its nature or context," is either to intimidate people "or" to coerce a government or international organization to act. ${ }^{83}$ Whereas the former is very broad to the extent that it can apply, for example, to gang activities committed with the conscious objective of intimidating, the latter partly signals the political aspect of terrorism. However, coercing a State in itself is wide enough to include acts that have no political, religious, or ideological rationale, ${ }^{84}$ such as the assassination of a judge carried out by a criminal syndicate to compel a State to abandon investigations or prosecutions. It seems that the drafters were reluctant (or found it controversial) to rely on motive to differentiate private from public violence, ${ }^{85}$ and they preferred to stick with the traditional criminal principle that "no motive can excuse an intentional crime." 86 Article 14 of the Terrorist Financing Convention reflects this in the provision that, for the

8I. U.S. President (1993-200I: Clinton), International Convention for Suppression of Financing Terrorism: Message from the President of the United States, Treaty Doc. Io6-49, Io6th Congress, 2d Sess., Senate Committee on Foreign Relations, at VII (2000), https:// catalog.hathitrust.org/Record/oIr329935.

82. Michael Walzer, Just and unjust wars: A moral argument with historical illustrations (3d ed. 2000); see also Thomas M. Franck \& Scott C. Senecal, Porfiry's proposition: Legitimacy and terrorism, 20(2) VAND. J. TRANSNAT'L L. 195 (I987).

83. During the negotiation on the Convention, concern was made that "there could be other reasons for committing a terrorist act." See U.N. Doc. A/C.6/54/L.2, supra note Io, Annex III, 987.

84. Aust, supra note 20, at 298.

85. See United Nations Office on Drugs and Crimes, Guide for the legislative incorporation and implementation of the universal ati-terrorism instruments (2006), 93 I.

86. Roach, supra note 34, at 42. 
purpose of extradition, a terrorist act shall not be viewed "as a political offence or as an offence connected with a political offence or as an offence inspired by political motives."

\section{CRIMINALIZATION OF TERRORIST FINANCING: JUSTIFICATIONS AND CHALLENGES}

Although the draft Terrorist Financing Convention was proposed with the intention of addressing terrorist financing independently, some doubted whether and, if so, how an ancillary act of financing could become the crime of terrorist financing. Three approaches were proposed and discussed during the negotiations on the draft Convention: (I) to treat terrorist financing as an ancillary form of participation in the offense of terrorism; (2) to criminalize only the acts of financing of terrorist groups; and (3) to consider terrorist financing as an independent crime. Relying too heavily on the assumption that terrorism is closely connected to organized crimes, FATF also calls on States to criminalize terrorist financing as a predicate crime to money laundering. These approaches will be discussed in this section.

\section{A. Terrorist Financing as an Ancillary Form of Participation in the Offense of Terrorism}

During the first and second reading of the draft Convention, reservations were expressed about whether it was necessary to separately and independently criminalize terrorist financing. ${ }^{87}$ It was argued that having an ancillary nature, the financing of any of the existing offenses defined by the sectoral conventions would constitute participation or complicity in that offense, and the provisions on accomplices in the sectoral conventions were enough to cover such financing. ${ }^{88}$ Although rejected by the drafters of the Convention, similar reasoning was given by some jurisdictions for refusing to establish an independent offense of terrorist financing. Aruba, for example, expressed the view that "several parts of the terrorist financing offences" as required by the Convention could be covered by the various existing provisions on accomplices in Aruba law. ${ }^{89}$ In addition, it was

87. U.N. Doc. A/54/37, supra note 9, Annex IV, ๆ $84-86$.

88. Aust, supra note 20, at 288.

89. Caribbean Financial Action Task Force, Mutual evaluation report: Anti-money laundering and combating the fianncing of terrorism: Aruba, Kingdom of the Netherlands, II I5O 
argued that a separate and independent offense might overlap some of existing crimes under its law. ${ }^{90}$

In some jurisdictions, terrorist financing may alternatively be considered as approaching the notion of an inchoate crime in the sense that its criminality is not dependent on the completion of a subsequent offense. In the Netherlands, for instance, the financing of a terrorist act used to be prosecuted as "preparation of an offence" under Article 46 of the Dutch Penal Code. ${ }^{91}$ The Dutch Supreme Court in a ruling defined "preparation" as "an incomplete form of a criminal offence." Widening the scope of the law on attempt, the court also ruled that "punishable preparation is further away from the completed offence than attempt... but involves acts in which perpetrator... intentionally fabricate[s] or ha[s] at his disposal means that are... intended for the commission of the criminal offence he has in mind." 22 In the case of terrorist financing, it seems that the financing of specific terrorist acts had included the situation where the act financed or intended to be financed has not been attempted yet. ${ }^{93}$ However, in spite of these objections the Netherlands amended its law in 2013 to meet the FATF's requirements by criminalizing the financing of terrorist acts as an autonomous offense. ${ }^{94}$

\section{B. Criminalization of Financing of Terrorist Organizations}

A minority of delegations tried a different approach. They sought to restrict the scope of the offense of financing only to terrorist organizations. ${ }^{95}$ They argued that a mere preparatory act cannot be criminalized as an

(Oct. I6, 2009), https://www.cfatf-gafic.org/index.php/documents/cfatf-mutualevaluation-reports/aruba-2.

90. Aruba has amended its law to satisfy the FATF's requirements and introduced a new offense of terrorist financing. However, it is not clear how Aruba addresses the overlap issue (a separate and independent offense might overlap with some of existing crimes under its law). See FATF, Mutual Evaluation of Aruba, Kingdom of the Netherlands: 8th Follow-up Report, III (Feb. 20I4), http://www.fatf-gafi.org/publications/mutualevaluations/ documents/fur-aruba-20I4.html.

9I. FATF, Mutual Evaluation Report: Anti-money laundering and combating of the financing of terrorism: the Netherlands, I 25I (Feb. 25, 20II).

92. Id. 9254.

93. Id. ๆ 270.

94. FATF, Mutual Evaluation of the Netherlands: 2nd Follup-up Report I7 (Feb. I4, 20I4). 95. See, e.g., Austria's proposal in U.N. Doc. A/AC.252/1999/WP.II, reproduced in U.N. Doc. A/54/37, supra note 9 , at 29. 
independent offense, unless the act is of a "particularly dangerous nature." According to these delegations, a "particularly dangerous" act should include "only" the financing of terrorist organizations. In fact, it was argued, "it is this aspect of organisation, which typically includes long-term planning, continuity of purpose, and division of labour and particular difficulty of detection, which renders entities and their activities so dangerous that criminalizing the financing of mere preparatory acts justifiable." 96 They expressed that a similar rationale could not apply to the financing of terrorist individuals as it would simply be a participatory offense (as discussed above), which falls within the scope of the sectoral conventions listed to the Convention. Such a reference to terrorist organizations required the introduction of the precise and detailed elements of the definition of "organization." 97 Although most of the proposed definitions of "organization" emphasized the hierarchical structure of a group of persons with common objectives, ${ }^{98}$ the drafters began to raise doubts over the "usefulness" of defining organization. ${ }^{99}$ The Convention was finalized, and the drafters avoided including a definition of "organization" in the view that the definition may vary from one case to another. ${ }^{100}$

Even the U.N. Security Council, which has engaged in the suppression of the financing of groups associated with al-Qaida as another method of countering terrorist financing, has failed to define a "terrorist organization" or provide legal guidelines for identifying terrorist groups. Instead, it has adopted an operational or listing and de-listing approach to the issue. ${ }^{101}$ The Security Council in Resolution I267 (1999) established a committee, ${ }^{102}$ namely the Al-Qaida Sanctions Committee, and gave it a mandate to create and update a list of individuals, groups, undertakings, and entities

96. Id.

97. U.N. Doc. A/54/37, supra note 9, Annex IV, ๆ II.

98. See, e.g., U.N., A/AC.252/1999/WP.6, reproduced in U.N. Doc. A/54/37, supra note 9, at 27. See also U.N. Doc. A/C.6/54/WG.I/CRP.6, reproduced in U.N. Doc. A/C.6/54/L. 2, supra note IO, at 2I.

99. Marja Lehto, Indirect Responsibility For terrorist aCts: REDEFINITION OF THE CONCEPT OF TERRORISM BEYOND VIOLENT ACTS 274 (2009).

Ioo. U.N. Doc. A/C.6/54/WG.I/CRP.35/Rev.I, reproduced in U.N. Doc. A/C.6/54/L.2, supra note IO, at $5 \mathrm{I}$.

IOI. $\mathrm{KoH}$, supra note 79 , at 97.

IO2. S.C. Res. I265, ๆ 6, U.N. Doc. S/RES/ı267 (Oct. I5, 1999). 
associated with al-Qaida. ${ }^{103}$ Having regard to the information provided by the member States and regional organizations, ${ }^{104}$ the committee, which consists of the Security Council member States, is obliged to make a decision (by "consensus of its members") on whether an individual or organization proposed is eligible to be designated as terrorist or de-listed. ${ }^{105}$ However, the inclusion of a group on the list provided by the U.N. Security Council is not always considered as "conclusive evidence" of the terroristic nature of that group. In this regard, an Italian court argued that the list has merely "an administrative value," which does not "override the principle of the free assessment of evidence by an independent judge."106

Designating an individual or group as terrorist without instituting criminal proceedings is also adopted by some States. For instance, in the United States, a group may be designated as a terrorist group by the Secretary of State in consultation with the Attorney General and the Secretary of the Treasury. ${ }^{107}$ The main criterion used to designate a group as terrorist is that the group engages in terrorist activity or "retains the capability or intends to engage in terrorist activity or terrorism." 108 This approach, however, is subject to criticism because of the lack of a certain legal base and procedure for designating individuals or groups and freezing their assets. ${ }^{109}$ In fact, this approach reduces the degree of judicial control of the designation process, and instead, politicizes the targeting process, ${ }^{110}$ which increases the risk of failure to abide by fundamental principles including the right to a fair hearing, "due process, right to property and freedom of association." 111

I03. S.C. Res. I390, ๆ 2, U.N. Doc. S/RES/1390 (Jan. I6, 2002); S.C. Res. I989, U.N. Doc. S/RES/I989 (June I7, 20II).

I04. S.C. Res. I390, I 5 (a).

I05. U.N. Security Council, Guidelines of the Committee for the Conduct of its Work 2 (Apr. I5, 2013), https://www.un.org/sc/suborg/en/sanctions/1267/committee-guidelines.

Io6. Italy v. Abdelaziz \& Ors, Final Appeal Judgment, No. I072; ILDC 559 (IT 2007).

I07. U.S. Department of State, Foreign Terrorist Organizations (Aug. 2017), http://www. state.gov/j/ct/rls/other/des/123085.htm.

I08. Id.

io9. Raphael Bossong, The evolution of EU counter-terrorism: European SECURity policy after 9/iI, at 48, Contemporary terrorism studies (2OI3).

IIO. Julie B. Shapiro, The politicization of the designation of foreign terrorist organizations: The effect on the separation of powers, 6(3) Cardozo PuB. L., POL'y, \& ETHICS J. 547 (2008).

III. U.N. Chairman of the Security Council, Letter dated I4 February 2005 from the Chairman of the Security Council Committee established pursuant to resolution I267 
In addition, the lack of a definition of a terrorist group or legal requirements for identifying terrorist organizations has resulted in disagreement among States and international organizations about which organizations or individuals should be listed or de-listed. ${ }^{112}$ In this regard, it is instructive to compare the list of States' and international organizations' blacklisted terrorist organizations since "there are notable omissions." 113

The importance of addressing the organizational character of the offense of terrorism, however, has been highlighted by the European Council through its establishment of terrorist group offenses. The E.U. Council Framework Decision of June I3, 2002, on Combating Terrorism, in Article 2(2), requires E.U. member States to criminalize "directing a terrorist group" as well as "participating in the activities of a terrorist group including by supplying information or material resources or by funding its activities in any way, with knowledge of the fact that such participation will contribute to the criminal activities of the terrorist group." 114 Similar to the definition of "organized criminal group" provided by the 2000 United Nation Convention against Transnational Organized Crime, ${ }^{115}$ the Framework Decision defines a terrorist group as a "structured group of more than two persons which [has been] established over a period of time and [is] acting in concert to commit terrorist offences." "116 A "structured group" is "a group that is not randomly formed for immediate commission of an offense and

(1999) concerning Al-Qaida and the Taliban and associated individuals and entities addressed to the President of the Security Council, U.N. DOC. S/2005/83 (Feb. I5, 2005), ๆ 50.

II2. The European Union-U.S. friction is a good example in this regard. Although the United States and Israel pressures the European Union to list Hamas and Hezbollah in its terrorist list, E.U. members differentiate between the military and political wings of these groups, including only the military wing of the groups to its list. For more discussion, see Bianca C. Hostetler, The European Union: expand, Shrink or status Quo 73 (2006).

II3. Alex Peter Schmid, Introduction to the world directory of extremist, terrorist and other organizations associated with guerrilla warfare, political violence, protest, organized crime and cyber-crime, in The Routledge handbook of terrorism research 350 (Alex Peter Schmid ed., 20II).

II4. E.U. Council, Framework on Combating Terrorism (2002/475/JHA), Art. 2(2)(a), (b).

II5. G.A. Res. $/ 55 / 25$, U.N. Doc. A/RES/55/25 (Nov. I5, 2000). Art. 2(a) of this convention defines a criminal group as "a structured group of three or more persons, existing for a period of time and acting in concert with the aim of committing one or more serious crimes or offenses established in accordance with this Convention, in order to obtain, directly or indirectly, a financial or other material benefit."

II6. E.U. Council, Framework on Combating Terrorism (2002/475/JHA), Art. 2(I). 
that does not need to have formally defined role for its members, continuity of its membership or a developed structure." It is worth noting that the FATF provides a wider definition in the sense that it does not require of a terrorist organization some measure of structure or the time factor. ${ }^{117}$

The Framework Decision is applied by European Union's member States, but using somewhat different interpretations. ${ }^{118}$ For instance, the financing of a terrorist organization in the Netherlands comes close to the notion of inchoate crime, ${ }^{119}$ but as discussed above, it does not merge into the category of a preparatory offense in the sense that a direct relation between the act of financing and a specific terrorist act is not necessary. ${ }^{120}$ In other words, the Netherlands criminalizes the financing of a terrorist group as "participation" in the group under Article I4Oa of the Penal Code. In general, participation in a group whose aims are to commit offenses is regarded as "the preparatory acts of entering into and maintain a longlasting collaboration, which is aimed at commission of the crime." ${ }^{121}$ In the case of terrorist financing, Article I4Oa does not require that the funds collected and provided be used, or intended to be used, for the commission of a specific act. The requirement is that the funds should be collected or provided for the "benefit" of a terrorist organization. ${ }^{122}$

Spain criminalizes the financing of a terrorist group as "belonging" to the group. ${ }^{123}$ According to Article 57I(3) of the Spanish Criminal Code,

II7. The FATF reduces the concept of terrorist groups to broadly cover "any group of terrorists that: (i) commits, or attempts to commit, terrorist acts by any means, directly or indirectly, unlawfully and wilfully; (ii) participates as an accomplice in terrorist acts; (iii) organises or directs others to commit terrorist acts; or (iv) contributes to the commission of terrorist acts by a group of persons acting with a common purpose where the contribution is made intentionally and with the aim of furthering the terrorist act or with the knowledge of the intention of the group to commit a terrorist act." FATF, FATF Recommendations: International Standards on Combating Money Laundering and the Financing of Terrorism and Proliferation I23 (Feb. 2012; update Oct. 2016).

II8. See Commission of the European Communities, Report from the Commision based on Article II of the Council Framework Decision of I3 June 2002 on combating terrorism (Brussels, Nov. 6, 2007).

II9. Caroline M. Pelser, Preparation to commit a crime: the Dutch approach to inchoate offences, 4(3) UtRecht 57, 70 (Dec. 2008).

I20. $I d$.

I2I. Id.

I22. FATF: Netherlands, supra note 91, ๆ 280.

I23. FATF, Third mutual evaluation report on anti-money laundering and combating the financing of terrorism: Spain, \\ II3, I24 (June 23, 2006). 
terrorist organizations are those groups that (I) are formed by a large number of persons, (2) possess weapons or dangerous instruments, and (3) have the particular purpose of "subverting the constitutional order or seriously breaching public peace." The financing of such a group under Article 576(I) of the Spanish Criminal Code is considered an act of "collaboration with the activities or the purposes of a terrorist organisation." "Collaboration," in Article 576(2), is defined as the provision of "information on . . or use of accommodation or storage facilities; concealment or transport of individuals related to terrorist organisations or groups;... and, in general, any other equivalent form of co-operation, aid or mediation, economic or of any other kind whatsoever, with the activities of those terrorist organisations or groups." Similar to the approach taken by Spain, some other IberoAmerican countries do not establish an independent offense of terrorist financing. Argentina, for example, illegalizes terrorist financing as "illicit association" to a terrorist organization (Article 2IO of its Criminal Code). ${ }^{124}$ Or Colombia, in Article 340 of its Criminal Code, treats terrorist financing as an agreement to commit crimes, ${ }^{125}$ which is similar to the concept of conspiracy in common law countries.

\section{Terrorist Financing as an Independent Offense}

Despite the above-mentioned approaches, the tendency in the negotiations on the draft Convention was toward retaining an independent offense of terrorist financing. ${ }^{126}$ The idea that the provisions on accomplices in the sectoral conventions were sufficient to cover all aspects of terrorist financing was rejected. Instead, it was argued that the financing of a terrorist act, in and of itself, is as serious an offense as the actual terrorist act. ${ }^{127}$ This notion is based on the assumption reflected in the preamble of the Convention: "the number and seriousness of acts of international terrorism depend on the financing that terrorists may obtain"; ${ }^{128}$ so it was concluded that the financers of terrorism should

I24. Yara Esquivel Soto, An autonomous offence for the financing of terrorism: Notes from an Ibero-American perspective, in Countering TERrorist FINANCING: THE PRACTITIOnER's POINT OF VIEW I98 (Mark Pieth, Daniel Thelesklaf, \& Radha Ivory eds., 2009).

I25. Id.

I26. U.N. Doc. A/54/37, supra note 9, Annex IV, ๆ 84.

I27. Aust, supra note 20, at 288.

I28. Terrorist Financing Convention, supra note I, Preamble. 
be punished as severely as those who commit terrorism. ${ }^{129}$ The application of this approach can be seen in Australia, where the penalty for the commission of terrorism financing is equal to that for the commission of terrorism, ${ }^{130}$ or in France, where under Article 42I-2-2 of French Criminal Code, "it constitutes an act of terrorism to finance a terrorist organisation." It seems that the drafters were determined to give the new offense a broad scope that covers "the financing of any and all crimes" defined by or annexed to the Convention. ${ }^{131}$

This approach is also justified in academia with regard to the harmful and dangerous nature of the act of terrorist financing. It is argued that terrorist financing should be considered to constitute "a separate primary harm rather than an ancillary harm" since "reliable financing" can change the conventional harm of terrorism from "sporadic and local" and give it a "continuous and broader nature" by enabling terrorists to expand the scale and scope of their influence across vast areas and expose numerous people. ${ }^{132}$ The example given is how solid resources enable terrorist groups such as the FARC and al-Qaeda to recruit members, supply them with adequate weapons, and launch and expand their activities anywhere in the world.

The injurious and dreadful consequences of terrorism also serve an important function in the construction of terrorist financing as an independent offense. ${ }^{133}$ It is argued that terrorist offenses are "multi-offensive" in that they endanger many "protected values" such as "life, physical integrity, property, freedom and national security." 134 As terrorist financing allows terrorism to become real, the act of financing terrorism poses ex ante threat to those values, too. This is sufficient justification to extend the reach of criminal law to include the criminalization of the preparatory act of terrorist financing as an autonomous crime. ${ }^{135}$

The criminalization of terrorist financing should be also regarded as a part of "a larger shift in criminal justice from an offender-oriented

I29. Aust, supra note 20, at 288.

130. Compare Art. IOI.2 with Art. I02.6 of the Criminal Code Act 1995 (Austl.).

I3I. LEHTO, supra note 99, at 274.

I32. $\mathrm{KoH}$, supra note 79, at 66.

I33. LeHTO, supra note 99, at 264

I34. Soto, supra note I24, at 200.

I35. Id. at 203 . 
towards a proceeds-oriented approach," 136 which has been specifically developed in the fight against organized crime that produces large profits for criminals. The main justification for the adoption of this approach is its "possible deterrence value." 137 It is believed that attacking the root of all economically motivated crimes would undermine the incentive of perpetrators to commit those crimes. ${ }^{138}$ At an organizational level, "going after the money" is assumed to incapacitate criminal organizations by taking away their financial lifeblood, "eliminating their capacity to trade and reducing their attractiveness to recruits." 139

The criminalization of money laundering is the key component of this approach since criminals may hide the proceeds with third parties ${ }^{140}$ or give them a legitimate appearance so that confiscation is not possible. ${ }^{141}$ So, for the sake of the confiscation of such proceeds, criminalizing laundering can provide a legal tool for law enforcement authorities to deal with suspicious property and assets, either in the hand of third parties or the real owner, ${ }^{142}$ without requiring the prosecution to prove beyond a reasonable doubt the guilt of the criminals of the predicate crime. ${ }^{143}$ That is, confiscation is possible by proving the charge of money laundering conduct or the "ownership" of the proceeds. In addition, the fight against money laundering is considered as a means of collecting evidence against the higher-level criminals who stay aloof from criminal activities, but who do come into contact with the proceeds derived from the criminal activities. ${ }^{144}$ This contact provides a paper trail of records that

136. Guy Stessens, Money laundering: A new international law enforcement model 85, Cambridge Studies in international and COMparative LaW (2000).

137. Michael Levi, Taking the Profit Out of Crime: The UKexperience, 5(3) Eur. J. Crime, Crim. L., \& Crim. Just. 228 (I997).

138. Ethan A. Nadelmann, Unlaundering Dirty Money Abroad: US Foreign Policy and Financial Secrecy Jurisdictions, I8(I) Inter-Amer. L. ReV. 33, 34 (1986).

I39. Levi, supra note I37, at 228.

I40. Frank Verbruggen, Proceeds-oriented criminal justice in Belgium: backbone or wishbone of a modem approach to organised crime?, 5(3) Eur. J. Crime, Crim. L., \& CRIM. Just. 3I4, 318 (1997).

I4I. $\mathrm{KOH}$, supra note 79 , at 39 .

I42. Stessens, supra note $\mathrm{I36}$, at 86.

I43. $\mathrm{KoH}$, supra note 79 , at 43.

I44. STESSENS, supra note I36, at 86. 
demonstrate the involvement of the top criminals in the criminal activities (predicate crime) from which the proceeds derived.

Regardless of how effective the application of this approach has been in the fight against organized crime, ${ }^{145}$ the logic of this argument hardly fits into the case of terrorism and terrorist financing. Firstly, it should be noted that terrorism is not a crime committed for the purpose of making money. It is a "politically motivated act of violence" 146 with two distinctive financial characteristics: (I) terrorists need less money to act than those criminals who seek to maximize their financial gains; ${ }^{147}$ (2) terrorist funds are derived from legal and illegal sources. Taking these facts into account, it seems implausible to argue that going after terrorists' funds undermines their incentive simply because funding terrorism is "a product of an ideology." ${ }^{448}$ As long as there is a desire for politically or ideologically inspired people to seek their purposes through violence, they will discover a way to do so. In terms of an impact on the organizational capacity of terrorist groups, although drying up terrorists' funds may have disruptive effects on the group's ability to recruit and conduct operations on the scale of the September II, it does not necessarily result in deterring or resolving "terrorism risks." ${ }^{149}$ Instead, it may reshape the risks in the sense that, as the case of al-Qaeda shows, a hierarchical (single-centralized) group may be replaced by smaller, decentralized groups ${ }^{150}$ that individually seek

I45. R.T. Naylor, Follow-the-money methods in crime control policy, in CRITICAL REFLECTIONS ON TRANSNATIONAL ORGANIZED CRIME, MONEY LAUNDERING, AND CORRUPTION (Margaret E. Beare ed., 2003). See also Peter Alldridge, The moral limits of the crime of money laundering, 5(I) Buff. CRIM. L. Rev. 279 (2002).

i46. Robin Morgan, The demon lover: The roots of terrorism 40 (rev. ed., 200I).

I47. Michael Levi, Lessons for countering terrorist financing from the war on serious and organized crime, in Countering the FINANCING OF TERRORISM 267 (Thomas J. Biersteker \& Sue E. Eckert eds., 2008).

I48. Raphael Perl, Anti-terror strategy, the 9/II Commission Report, and terrorism financing: implicating for U.S. policy makers, in TERRORISM FINANCING AND STATE RESPONSES a comparative perspective 255 (Jeanne K. Giraldo, Harold A. Trinkunas, \& ebrary Inc. eds., 2007).

I49. Levi, supra note 2, at 662.

I50. National Commission on Terrorist Attacks upon the United States, The 9/II Commission report: Final report of the National Commission on Terrorist Attacks upon the United States (2004), at 383. See also U.N. Chairman of the Security Council, Letter dated 23 August 2004 from the Chairman of the Security Council Committee established pursuant to resolution 1267 (1999) concerning Al-Qaida and the Taliban and associated individuals 
damaging sets of scattered attacks. ${ }^{151}$ Therefore, the amount of money these groups would seek "would be much smaller; the means used to raise them would vary widely and depend on the local conditions,... there would be much less need for fund transfers and the communication among groups... would be minimal." 152 A concern is raised that if terrorist networks become increasingly decentralized and self-funding, it is much harder for authorities to track and capture their funds. ${ }^{153}$ This also challenges the assumption that "terrorists need a financial support network." 154 It is worth noting that similar conclusions were drawn by many regarding efforts to interrupt finances of organized crime. ${ }^{155}$

Although the freezing and confiscation of the proceeds of criminal activities can be facilitated by criminalizing money laundering techniques, attacking terrorist financing at an early stage is regarded as "premature and problematic." 156 The main problem in this regard derives from the fact that the nature of terrorist financing is "the inverse of the structure of the money laundering offence." 157 Although money laundering cases are based on predicate offenses that have already taken place, the principal offense on which terrorist financing is premised, in most cases, is not yet committed or even attempted. Freezing such funds appears to be much more difficult in terrorist financing than in money laundering cases, as the law enforcement agencies need to establish a hypothetical link between the suspicious funds and a possible terrorism connection. From a practical viewpoint, as the 9/II Commission Report indicates, focusing on the freezing strategy may also negate any chance of intelligence and law enforcement agencies to monitor the movement and transfers of those

and entities addressed to the President of the Security Council, U.N. Doc. S/2004/679 (Aug. 25, August 2004), 96.

I5I. Levi, supra note 2, at 662.

152. Nikos Passas, Terrorism financing mechanisms and dilemmas, in Terrorism financing and state Responses: A comparative perspective 32-33 (Jeanne K. Giraldo \& Harold A. Trinkunas eds., 2007).

I53. Perl, supra note I48, at 251.

I54. National Commission on Terrorist Attacks upon the United States, supra note I50, at 382. See also John Roth and others Monograph on terrorist financing staff report to the Commission (National Commission on Terrorist Attacks upon the United States, Washington, D.C., 2004), at 29.

I55. Perl, supra note I48, at 25I. See also Levi, supra note 2, at 662.

156. Passas, supra note I52, at 36.

I57. Boister, supra note 29, at Io6. 
funds, understand terrorists' networks, and consequently search them out and disrupt their operations. ${ }^{158}$

\section{Terrorist Financing as a Predicate Offense to Money Laundering}

Following the adoption of the Terrorist Financing Convention, the FATF now also emphasizes the criminalization of terrorist financing as an independent offense; but referring to "the close connection between international terrorism and, inter alia, money laundering,"159 it additionally pushes countries to criminalize terrorist financing as a predicate crime to money laundering. ${ }^{160}$ There are, nonetheless, some uncertainties about the scope of this FATF recommendation. Practically, it is not clear what the reference to the link between terrorism and money laundering implies. Does it mean that terrorism is a crime that generates proceeds that need to be laundered? This has had an impact at a national level. India, for example, defines "proceeds of terrorism" as "all kinds of properties which have been derived or obtained from commission of any terrorist act or have been acquired through funds traceable to a terrorist act." ${ }^{161}$ Whereas "terrorism" is defined by the Convention as the use of violence against civilians that results in bodily injury for the purpose of intimidating or coercing, it seems that India either is confusing terrorism with the acts carried out by terrorists or their financiers to raise funds for terrorist purposes, or intends to label any acts executed by terrorists as terroristic. The consequence of such an interpretation would be criminalization of persons rather than their conduct.

In addition, terrorist financing logically does not fit into the money laundering scheme. Terrorist financing does not necessarily involve money laundering activities since the source of funds and the direction of financial flows in terrorist financing are considerably different from those in money laundering. ${ }^{162}$ Regardless of this fact, even if it is assumed that terrorist

158. National Commission on Terrorist Attacks upon the United States, supra note 150, at 382. See also Passas, supra note 152, at 36.

159. FATF: Recommendations, supra note II7, interpretive note to Recommendation 5, at 37 .

I6o. Id., Recommendation 5, at I3.

I6I. See Chapter I (2)(g) of Unlawful Activities (Prevention) Act 1967 (India).

i62. See Roberto Durrieu, Rethinking money laundering \& Financing of TERRORISM IN INTERNATIONAL LAW: TOWARDS A NEW GLOBAL LEGAL ORDER, esp. ch. I (2013). 
financing includes money laundering activities or is another form of money laundering (so-called reverse-money laundering), ${ }^{163}$ it does not make any sense at all to criminalize a form of money laundering (terrorist financing) as a predicate offense to another crime (money laundering). Probably to avoid this inconsistency, in Article 2(d) of its Anti-Money Laundering Statute, Saudi Arabia mistakenly considers terrorist financing as a form of money laundering, rather than establishing an independent offense of terrorist financing as a predicate offense to money laundering. ${ }^{164}$

\section{THE ANALYSIS OF THE ELEMENTS OF THE CRIME OF TERRORIST FINANCING}

The drafters of the Terrorist Financing Convention obviously struggled with introducing terrorist financing as an autonomous offense. This is not only because delineating the elements of the new offense of financingwhich, in most cases, is in itself victimless, harmless, and preparatory in nature-is difficult and controversial, but also because the drafters could not succeed in providing a precise and comprehensive definition of "terrorism," "terrorist," and "terrorist group," the financing of which should be independently criminalized. Under the shadow of such a failure, the result could not be expected to be promising. Neither could it be hoped that the criminalization of terrorist financing, as it was finalized, would be easily accepted and similarly understood or practiced by State parties to the Convention. This section is devoted to showing how the negotiations on the elements of the crime of terrorist financing took place, and how such criminalization is understood and implemented at national levels.

\section{A. The Elements of the Offense of Terrorist Financing}

The finalized draft of the Convention defines the basic terrorist financing offenses in Article 2(I) as follows:

I63. Stefan D. Cassella, Reverse money laundering, 7 J. Money Laundering Control 93 (2003).

164. Middle East \& North Africa Financial Action Task Force, Mutual evaluation report: Anti-money laundering and combating the financing of terrorism: Kingdom of Saudi Arabia, 9 I49 (June 25, 2010). 
Any person commits an offence within the meaning of this Convention if that person by any means, directly or indirectly, unlawfully and wilfully, provides or collects funds with the intention that they should be used or in the knowledge that they are to be used, in full or in part, in order to carry out: (a) [a]n act which constitutes an offence within the scope of... [annexed conventions]; or (b) [a]ny other act intended to cause death and serious body injury to a civilian....

The Convention in Article 2(3) gives different meaning to this definition by adding that "[f] or an act to constitute an offence set forth [in Article 2(I)], it shall not be necessary that the funds were actually used to carry out an offence" annexed to the Convention or the offense of terrorism defined by the Convention.

\section{Controversy on the definition of the term "funds"}

Before examining the elements of the offense of terrorist financing provided in the above-quoted paragraph, attention is needed to the term "funds" to which reference is made. Despite the first ${ }^{165}$ and revised draft 166 of the Convention in which the term "funds" was used in a generic definition that encompassed "any form of pecuniary benefit," 167 the drafters decided to stretch the meaning of the term beyond its dictionary definition. The Convention extends the meaning of the funds to cover

assets of every kind, whether tangible or intangible, movable or immovable, however acquired, and legal documents or instruments in any form, including electronic or digital, evidencing title to, or interest in, such assets, including, but not limited to, bank credits, travellers cheques, bank cheques, money orders, shares, securities, bonds, drafts, letters of credit. ${ }^{168}$

This definition seems to include anything under the sun, from "animals, buildings, or vehicles of any kind" to any other objects with pecuniary value. ${ }^{169}$ Under such a definition, the title of the Convention would be more precisely titled "material assistance" than "the financing of

165. See Permanent Rep. of France to the U.N., supra note 6, Art. I.

I66. U.N. Doc. A/54/37, supra note 9, Annex II, Art. I(I).

I67. Id., Annex IV, I Iо.

168. Terrorist Financing Convention, supra note I, Art. I(I).

169. Roberto Lavalle, The International Convention for the Suppression of the Financing of Terrorism, 6o Zeitschrift für Ausländisches Öffentliches Recht Und VÖlkERRECHT 49I, 496 (2000). 
terrorism." ${ }^{170}$ As illustrated in the discussion below, which examines both a very broad approach and more narrow approaches to interpreting "funds" and "funding," the apparent broadness of this definition, which may seem functional in the abstract, proves, however, to be controversial when applied at the national level.

\section{a. Definition of the term "funds": a broad but controversial interpretation.} The Convention does not clarify what the expression "but not limited to" refers to. From a U.S. perspective, which applies a very broad definition of support, this means support beyond pure funding. That is, U.S. law prohibits providing "material support or resources" to terrorists and foreign terrorist organizations. ${ }^{171}$ The term "material support or resources" includes not only funds and tangible goods, but also "training," "personnel," "transportation," "service," and "expert advice or assistance," "except medicine or religious materials." 172

However, the precise scope of the "material support and resourses" provisions has proved controversial and come under constitutional attack for their vagueness. The main challenge that U.S. courts have faced is deciding whether the support provided by groups seeking to advocate for human rights and peace to and with the organizations designated as terrorist organizations fits the definition of "material support and resources." 173 In the complicated twelve-year-long Humanitarian Law Project litigation, the plaintiffs claimed, among other things, that prohibitions against providing "material support and resources" to foreign terrorist organizations are "unconstitutionally vague." 174 Specifically, the plaintiffs sought to enjoin enforcement against the ban on providing "training,"

I70. $I d$.

I7I. I8 U.S.C. $\S \S 2339$ A, B.

I72. The U.S. Congress intended the term "medicine" "to be understood to be limited to the medicine itself, and does not include the array of medical supplies." The term "religious" should not be read to include "anything that could be used to cause physical injury to any person. It is meant to be limited to those religious articles typically used during customary and time-honored rituals or teaching particular faith, demonstration, or sect." See U.S. House of Representatives, Terrorism Prevention Act (Report number I04-518, April I5 1996), https://www.fas.org/irp/congress/1996_rpt/hio45I8.htm. See also I8 U.S.C. § 2339A(b)(I).

I73. Humanitarian Law Project v. Reno, 9 F. Supp. 2 d 1176 (U.S. District Court, C.D. California. 1998) ๆ II80.

I74. Id., ๆ $\mathrm{I185}$. 
"expert advice or assistance" (when derived from specialized knowledge), "service," and "personnel."

Despite the clarifying explanations of these terms added to the material support provisions, ${ }^{175}$ the District Court and the Court of Appeals ruled that these terms (except the term "personnel"176) are impermissibly vague. With regard to the term "training," which is defined as "instruction or teaching designed to impart a specific skill, as opposed to general knowledge," 177 the court accepted the plaintiffs' argument that the term "training" does not clearly "put a person of ordinary intelligence on notice that his or her contemplated action is unlawful" because it is highly improbable "that a person of ordinary intelligence would know whether, and when teaching someone to petition international bodies for tsunami related aid... is imparting a 'specific skill' or general knowledge," and because "a plaintiff who wishes to instruct members of a designated group on how to petition the United Nations to give aid to their group could plausibly decide that such protected expression falls within the scope of the term "training."' 178 The court stated that even if persons of ordinary intelligence could understand the scope of the term "training," the term would remain vague as it could still be read to cover speech and advocacy protected by the First Amendment. ${ }^{179}$

With regard to the term "expert advice or assistance," defined as imparting "scientific, technical or other specialized knowledge," 180 the plaintiffs argued that the "specialized knowledge" portion of this definition is unclear because "it merely repeats what an expert is and provides no

I75. I8 U.S.C. $\S \S 2339 \mathrm{~A}(\mathrm{~b})(2),(3), 2339 \mathrm{~B}(\mathrm{~h})$,

I76. The U.S. court in the case of Humanitarian Law Project v. Gonzales (380 F. Supp. 2d II34 (U.S. District Court, C.D. California, Western Division, 2005)) atII52 held that the amendment to the material support provisions (Art. $2339 \mathrm{~B}(\mathrm{~h})$ ) limits "prosecution for providing "personnel" to the provision of "one or more individuals" to a foreign terrorist organization "to work under terrorist organization's direction or control or to organize, manage, supervise, or otherwise direct the operation of that organizations." The provision also clarifies that "[i]ndividuals who act entirely independently of the foreign terrorist organization to advance its goal or objectives shall not be considered to be working under the foreign terrorist organization's direction and control."

I77. I8 U.S.C. $\S 2339 A(b)(2)$.

I78. Humanitarian Law Project v. Mukasey, 552 F.3d 916 (U.S. Court of Appeal, 9th Circuit, 2009) \ 929.

I79. Id.

I8o. I8 U.S.C. § $2339 \mathrm{~A}(\mathrm{~b})(3)$. 
additional clarity," 181 so "they must now guess whether their expert advice constitutes specialized knowledge."182 The Court of Appeals ruled that

\begin{abstract}
"specialized knowledge" includes the same protected activities that "training" covers, such as teaching international law for peacemaking resolutions or how to petition the United Nations to seek redress for human rights violations....[T]he phrase "scientific, technical, or other specialized knowledge" does not clarify the term "expert advice or assistance" for the average person with no background in law. ${ }^{183}$
\end{abstract}

The insertion of the undefined term "service" to the definition of the "material support" provisions has been also attacked on vagueness grounds. Emphasizing that the plaintiffs could freely engage in human rights and political advocacy "on behalf of" designated groups before any forum of their choosing, the defendants argued that the dictionary meaning of the term "service" - "an act done for the benefit or at the command of another" or "useful labor that does not produce a tangible commodity"-clarifies the scope of the prohibition on the provision of service. ${ }^{184}$ The plaintiffs opposed the defendants contradictory arguments, claiming that such a definition "forces the plaintiffs to guess whether human rights and political advocacy action taken 'on behalf of another, which [the] [d] efendants concede is protected action, or 'for the benefit of another', which [the] [d]efendants argue is prohibited."185 Adopting the District Court's reasoning and its holding, the Court of Appeal found the term "service" unconstitutionally vague because "the statute defines 'service' to include 'training' or 'expert advice or assistance', terms the court has already ruled are vague,"186 and because "it is easy to imagine protected expression that falls within the bounds of the term 'service."'187

The Supreme Court, however, reversed the Court of Appeals' decision on insufficient and controversial grounds. It found that the lower court inappropriately conflated the plaintiffs' vagueness challenge with their First

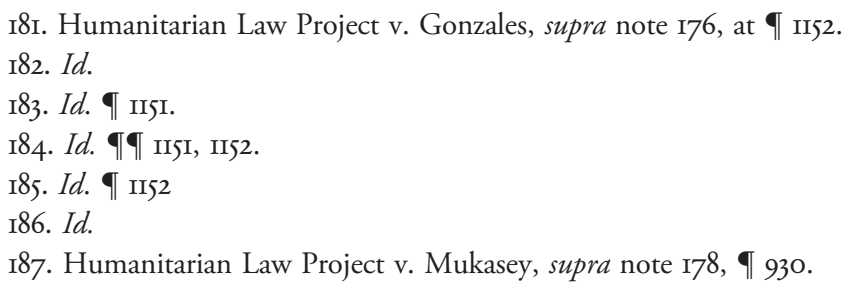


Amendment concerns. ${ }^{188}$ It claimed that the provisions survive scrutiny if each of those challenges is regarded independently. With regard to the vagueness challenge, the court criticized the lower courts' approach for examining the statute's application in any possible circumstances, not to the facts before them. ${ }^{189}$ Although acknowledging that "the materialstatute may not be clear in every application," 190 the Supreme Court upheld that most of the activities in which the plaintiffs wish to engage are clearly banned by the provisions. ${ }^{191}$ That is, a reasonable person would realize that training PKK (Partiya Karkerên Kurdistanê) ${ }^{192}$ members to use international law to resolve disputes or to petition the United Nations for relief falls within the scope of the terms "training" and "expert advice or assistance" because they impart a "specific skill," not "general knowledge." 193 The court found that political advocacy on behalf of the PKK or LTTE (Liberation Tigers of Tamil Eelam) ${ }^{194}$ may be also regarded as material support in the form of providing "personnel" or "service," the scope of which are extended by the statute to cover coordinated or directed, and not "independent," advocacy. ${ }^{195}$ The court refused to answer these questions asked by the plaintiffs: "How much direction or coordination is necessary for a conduct to constitute a 'service' or 'personnel'? Would any communication with any members be sufficient? Would a leader? Must the relationship have any formal elements, such as an employment or contractual relationship? What about a relationship through an intermediary?"196 The court found these questions too "hypothetical" to be considered. ${ }^{197}$

With regard to free speech claims, the Supreme Court, in a controversial ruling and for the first time in its history, ruled that the government may prohibit the provision of material support in the form of political advocacy of the type at issue to a terrorist organization without violating the First

I88. Holder v. Humanitarian Law Project, I30 S. Ct. 2705, 2719 (2010).

189. Id.

190. Id. at 2720 .

I9I. $I d$. 92719.

192. The Kurdish Workers' Party (the PKK) in turkey is designated as a terrorist in the US. See U.S. Department of State, supra note IO7.

193. Holder v. Humanitarian Law Project, supra note I88, ๆ 2720.

194. The Liberation Tigers of Tamil Eelam. See U.S. Department of State, supra note I07.

195. Holder v. Humanitarian Law Project, supra note I88, \ๆ 272I-22.

I96. Id. ๆ 2722.

197. Id. 
Amendment. ${ }^{198}$ Favoring urgent political demands, ${ }^{199}$ the court recited the government's concerns that foreign terrorist organizations are so tainted by their criminal conduct that training and coordinated support, which takes place in coordination with or at the direction of a terrorist organization, in the form of advocacy of a terrorist group's lawful activities, might be put to violent ends in the way that money, food, and other "fungible" resources could be. ${ }^{200}$ They may "lend legitimacy to foreign terrorist groups ... that makes it easier for those groups to persist, to recruit members and to raise funds." ${ }^{201}$ Providing foreign terrorist groups with material support in any form strains the United States' relationships with their allies and undermines their efforts to prevent terrorism. ${ }^{202}$ Terrorist groups acquainted with United Nations human rights bodies might use also the information to "threaten, manipulate and disturb." 203 Assisting groups to pursue peaceful negotiations might be used as "a means of buying time to recover from short-term setbacks, lulling opponents into complacency, and ultimately preparing for renewed attacks."204

The politically motivated decision of the court has been criticized mainly because neither the court nor the government provided any evidence to prove how the plaintiffs advocacy of human rights or peacemaking could be turned to terrorist activities. ${ }^{205}$ Regardless of its reliability, the court's reasoning is moot; that is, if the harm of political advocacy is adequate to justify the prohibition, why is it not sufficient to justify the ban on "independent" advocacy, which "is not directed by, or coordinated with, a designated terrorist organization," and which also might free resources, legitimatize groups, or give terrorists the opportunity of exploiting it for their illegal purposes?206 The court's reasoning also raised the concern that if the government does not intend to discriminately suppress particular advocacy for particular groups, why does not it ban (or should not have banned) the provision of "job training" to other groups such as gangs,

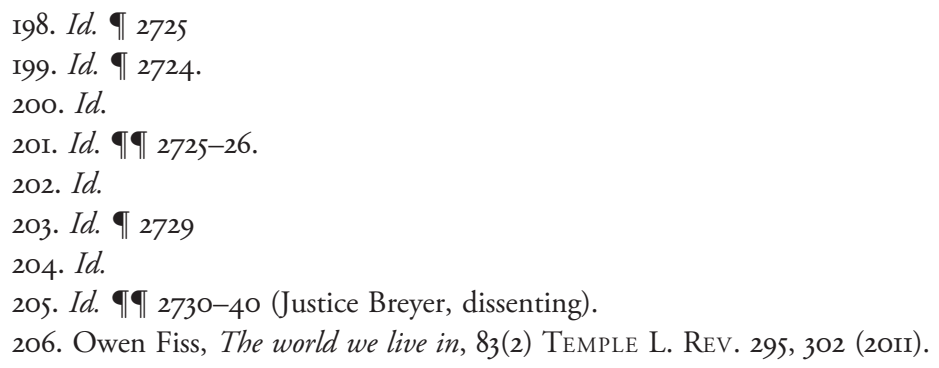


which might make them more effective criminals or lend them legitimacy? Or, should peaceful coordinated advocacy with activist nongovernmental organizations like Greenpeace be proscribed on the theory that these organizations sometimes use illegal methods to achieve their goals? ${ }^{207}$ Might advocating for de-listing a foreign terrorist group, which usually requires some degree of coordination with the organization, be considered as provision of material support in the form of "services" to the group? After the decision in the Humanitarian Law Project case, the answers to these questions may be yes, although they differ from questions addressed by the court. ${ }^{208}$

In a similar case, ${ }^{209}$ the Court of Appeals complicated the issue by holding that the First Amendment does not permit the government to proscribe advocacy coordinated with a "domestic" terrorist organization. Although it applied the decision in the Humanitarian Law Project case, the court reasoned that the coordinated advocacy for a designated group whose assets has already been frozen could not free up the group's assets for its illegal purposes simply and logically because there are no assets available. ${ }^{210}$ Nor does it endanger the United States' relationship with its allies as it is a domestic matter. ${ }^{211}$ However, neither the court nor the statute defined the term "domestic." 212

207. David Cole, The First Amendment's borders: The place of Holder v. Humanitarian Project in First Amendment doctrine, 6(I) Harvard L. \& Pol'y Rev. I47, I57 (2012).

208. With regard to advocacy for the Communist Party, which engaged in illegal activities, the court held that even teaching or advocating criminal conduct cannot be banned except where such teaching and advocacy produce incite and likely produce "imminent lawless action." See Brandenburg v. Ohio (395 U.S. 444, 448 (1996)). Or in De Jonge v. Oregon (299 U.S. 353 (1937), the court quashed the conviction of the defendant who engaged in speaking and recruiting on behalf of the Communist Party because he advocated lawful, nonviolent activities.

209. In Al Haramain Islamic Foundation, Inc. v. U.S. Department of Treasury (66o F.3d IOI9 (9th Cir., 20II)), a local community organization sought to engage in coordinated advocacy with a group designated as a domestic terrorist group to protest the designation, issue a press release and hold a press conference.

2IO. Id. ๆ 1053 .

2II. Id.

212. The court asserted that the designated group at issue in this case is "neither wholly domestic nor wholly foreign." But it is considered "domestic" because it is "incorporated" under U.S. law, it is "physically located" in the U.S., it has domestic bank accounts, and most of its activities are carried out in the U.S. The court, however, alleged that the groups had ties and interactions to and with foreign organizations. See id. II I052. 
b. Narrow definition of the term "funds". Unlike the United States and other member States that broadly define the term "funds," 213 some States limit the definition to pecuniary resources or to funds of a certain value. Following its proposal in the negotiations on the Convention, ${ }^{214}$ Japan, in Article 2 of the Act on the Punishment of Financing of Offences of Public Intimidation, uses the term shikin, which is the translation of the word "funds" and which is used and understood as "cash and monetary instruments easily convertible into cash." ${ }^{215}$ In the case of the law at issue, the scope of the term shikin has been also defined by the Ministry of Justice of Japan, under whose jurisdiction a law is enacted and applied, to include not only "cash and other means of payment," but also "other kinds of assets that are provided or collected with the intention of gaining such cash or other means of payment as a fruit or to be converted into such cash or other means of payment." 216

The scope of the term "assets" is also limited under German law by Section 89a(2), no. 4, of German Penal Code to comprise only assets that are not "insubstantial" in value. The term "insubstantial" is defined by the German Parliament to include movable and immovable property of a certain value. It was added that "assets [that] might be deemed insignificant when seen in isolation may be more than merely insubstantial if, in an overall evaluation, they have made a greater than merely insubstantial contribution to the preparation of a serious violence act endangering the state." 217 With regard to financing of terrorist groups, broadening the scope of term "assets," Section I29a (5) forbids provision of the "support" for terrorist groups. Although the term "support" is not defined, according to the Federal Supreme Court, "support" of a terrorist group includes "any objectively useful, supportive, and therefore also all types of provision of

213. In Art. 42I-2-2 of the French Penal Code, the reference to the term "funds" includes "funds," "securities or property of any kind," and "advice." Or in Art. I87A of Greek Penal Code, material support includes "information and material means," "funds" in the meaning of the Terrorist Financing Convention, and "financial means" of any kind.

2I4. In the negotiations on the Convention, Japan proposed the use of the generic definition of "funds" such as "any form of pecuniary benefits." U.N. Doc. A/AC.252/1999/ WP.Io, reproduced in U.N. Doc. A/54/37, supra note 9, at 28.

215. FATF, Third mutual evaluation report: Anti-money laundering and combating the financing of terrorism: Japan, 9219 (Oct. 17, 2008).

216. Id. ๆ 22I.

217. International Monetary Fund, Germany: Detailed assessment report on anti-money laundering and combating the financing of terrorism, 9207 (Mar. 2010). 
funding referred to under the [Terrorist Financing] Convention."218 However, the definition of a "terrorist group" within the meaning of the Section 129 is narrower than the definition provided by the FATF. ${ }^{219}$

Although the German approach has been criticized by the FATF, ${ }^{220}$ it should be noted that the drafters of the Convention did not take into account a similar suggestion put forward during the negotiations, which emphasized the fact that the Convention "should be carefully reviewed so as to avoid the criminalization of minor offences." 221

\section{The objective elements of the offense: What constitutes acts of financing?}

Defining the material act of the new offense is not as easy as one may imagine. It is because the act of financing, in its nature, is harmless and preparatory, and in many cases, has a legal appearance. Unsurprisingly, the drafters of the Convention struggled with clarifying how and when an act of financing turns into the crime of terrorist financing. In a revised draft of the Convention, the term "financing" was defined in a separate paragraph to mean "the transfer or reception of funds, assets or other property, whether lawful or unlawful, by any means, directly or indirectly, to or from another person or another organization." 222 However, such a definition provoked serious differences of opinion among the delegations.

The most controversial issue in this regard was whether the act of financing should include "the reception of funds in addition to their transfer." 223 A concern was expressed that the term "transfer" did not

2I8. Id. \ 22I.

219. According to $\S$ I29 of the German Criminal Code, a terrorist group is viewed to be "an organization combination of at least three persons, designed to exist for a certain period of time, where- with subordination of the will of the individual to the will of the group as a whole-the members pursue common goals, while standing in such relation to one another that they feel themselves to be a uniform cluster." Terrorist organizations are also those whose purposes or activities are aimed at committing the certain classes of crimes specified by the section.

220. The FATF experts believe that the imposition of a requirement for the finds to be of a certain minimum value is not fully in line with its requirements. See International Monetary Fund, supra note 217, ๆ 208.

22I. U.N. Doc. A/54/37, supra note 9, Annex IV, II4.

222. Id., Annex II at Art. I(I).

223. U.N. Doc. A/C.6/54/L.2, supra note Io, Informal summary of the discussions in the Working Group, prepared by the Chairman, 932. 
include all kinds of financial assistance. An alternative proposal was made to replace the term "transfer" with "providing, provisions" or "making funds available" "so as to make it clear that an actual transfer was not required per se," 224 and "to provide a broader scope of the term 'financing' beyond the technical connotation of 'transfer."'225

The retention of the term "reception" was also opposed on the basis that "it would cast the meaning of the term 'financing' too broadly, criminalizing a wide variety of activities beyond what was originally intended," from "active acts of financing" to "the passive act of receiving," 226 It was also pointed out that the term "financing" did not need to include the case of intermediaries who received funds as "the subsequent transfer of those funds would fall within the scope of the term 'transfer."'227

On the other hand, the retention of term "reception" was supported as it could enable authorities "to counter the funnelling of funds through middlemen, who possessed the specific intention required by the draft Convention, or through other similar complex financial arrangements used to finance terrorist acts." ${ }^{228}$ It was also pointed out that the deletion of the reference to "reception" would restrict the prosecution of the intermediaries who possesses funds but decline to transfer them or who get arrested before transferring them. A concern was expressed that if the delegations considered a reference to "reception" necessary, a specific intent element in relation to the act of reception should be defined. ${ }^{229}$ A relative suggestion was proposed in favor of the criminalization of the act of reception "as a separate offence to transferring." ${ }^{230}$ As a result of the divergent views on the definition of "financing," the drafters decided to delete the reference to the term "financing." In the final draft of the convention, the objective element of the offense was defined to mean the unlawful provision or collection of funds. ${ }^{231}$

224. Id. ๆ 35

225. U.N. Doc. A/54/37, supra note 9, Annex IV, ๆ 2.

226. U.N. Doc. A/C.6/54/L.2, supra note Io, Informal summary of the discussions in the Working Group, prepared by the Chairman, 937.

227. Id.

228. Id. 938

229. Id. \ 39.

230. $I d$. 940.

23I. Terrorist Financing Convention, supra note I, Art. 2(I). 
Although this definition was accepted by the delegations without any further argument, there are some uncertainties in regard to the application field of this definition. First of all, unlike the 2000 United Nations Convention Against Transnational Organized Crime (the Palermo Convention) in which the possession of proceeds is regarded as one of the material elements of money laundering, ${ }^{232}$ the Terrorist Financing Convention is vague on whether the terms "collection" and "provision" can be extended to cover the possession of funds. Different approaches have been adopted by various member States. For example, unlike Japan, ${ }^{233}$ the United Kingdom in Section 16 of Terrorism Act (2006) criminalizes the "possession" of money or property intended to be used or likely to be used for terrorism.

In addition, the replacement of the terms "transfer" and "reception" by the terms "collection" and "provision" without any explanation results in different understandings. The main question in this regard is, how should these two acts (collection and provision) be treated? On the one hand, in some jurisdictions, such as Portugal, the collection of funds is regarded as a preparatory act that constitutes "an attempt or preliminary form of attempt." 234 Similarly, in Spain, the financing of a terrorist organization constitutes an attempted offense when funds are collected in order to be provided to the terrorist group in the furtherance of its illegal aims and activities. ${ }^{235}$

On the other hand, some believe that "the collection of funds" and "the provision of funds" are two distinct acts, each of which represents "a separate offence." 236 It is argued that "although collecting funds may be a preparatory act to their provision, it is not a prerequisite to it since funds provided to terrorists need not have been the object of a prior collection."237 So if a person raises funds and then provides them to terrorists, he perpetrates two different, but successive, crimes. Moreover, in the case of the

232. United Nations, Convention against Transnational Organized Crime (Nov. I5, 2000), Art. 6(I)(b)(i).

233. Under Japanese Penal Code, the mere possession of funds does not constitute criminal labiality. See FATF: Japan, supra note 215, \ 224.

234. FATF, Third mutual evaluation report: Anti-money laundering and combating the financing of terrorism: Portugal, 9 I83 (Oct. I3, 2006).

235. FATF: Spain, supra note I23, \I I2I.

236. Lavalle, supra note 169 , at 498.

237. Id. 
involvement of intermediaries, the person who commits the collection offence is different from the person who perpetrates the provision offence. In such a case, however, the question may arise about whether the transfer of funds from collectors to intermediaries should be regarded as a collection or a provision? In the United States, where the term "collection" includes "raising and receiving" and the term "provision" means "giving, donating and transmitting," 238 a court did not try to differentiate between these two acts. It simply held that "the banking activities of receiving deposits and transmitting funds between accounts on the basis that the accounts (and funds) belong to groups engaged in terrorist activity" or charity fronts may create criminal liability under the U.S. law. ${ }^{239}$

It is worthy of note that in some jurisdictions, the illegality of an act of collection depends on who the financers are. In Japan, for example, the collection of funds for terrorist purposes does not create criminal liability if the collectors are not terrorists. ${ }^{240}$ Their acts will not be punishable unless and until they provide the collected funds to terrorists. ${ }^{241}$ In other words, the crime is never inchoate, only choate.

\section{The requirement of unlawfulness}

What gives an unconventional appearance to the Terrorist Financing Convention is the requirement of unlawfulness in Article 2(I); that is, funds have to be collected or provided "unlawfully." 242 As the German delegation in the negotiation pointed out, if the Convention aims at criminalizing the act of financing terrorism as an offense, "the mentioning that such financing has to be unlawful seems superfluous." 243 It should be noted that the same qualifier was used in the Terrorist Bombing Convention so as not to criminalize the lawful use of explosives. ${ }^{244}$ The application of this qualifier in this case is justified on the basis that nonmilitary people may

238. I8 U.S.C. $\S \S 2339 \mathrm{C}(\mathrm{e})(4),(5)$.

239. National Commission on Terrorist Attacks upon the United States, supra note I50, at 588 .

240. FATF: Japan, supra note 2I5, ๆ 2 I7.

24I. It should be noted that from the Convention's perspective, it does not matter who collects the funds. In other words, "any person" who supplies funds with terrorist purposes is liable.

242. Art. 2(I) of the Terrorist Financing Convention, supra note I.

243. UN, A/AC.252/1999/WP.26, reprinted in UN, A/54/ 37.

244. Art. 2(I) of the Terrorist Bombing Convention, supra note 15. 
lawfully use explosives for civilian purposes such as construction and mining; ${ }^{245}$ however, such a justification cannot be applied in the case of terrorist financing since the provision or collection of funds for use in committing terrorist acts cannot be legal in any event.

As far as the discussions in the travaux préparatoires of the Convention are concerned, the term "unlawfully" was included to add "an element of flexibility" to the definition by excluding from the ambit of the application of the Convention financing cases such as "ransom payments," ${ }^{246}$ or cases which "might have the unintended result of aiding the commission of" terrorist acts $^{247}$ such as the provision of material assistance to groups believed to pursue terrorist offenses as well as humanitarian activities. ${ }^{248}$ Similar concerns were expressed by the representatives of the International Committee of the Red Cross and the United Nations High Commissioner for Refugees, whose material assistance to groups of individuals (refugee camps were mentioned) might unintentionally fall into the hands of the guilty. ${ }^{249}$ It is also noted that the term "unlawfully" might be retained to mean "conduct undertaken without authority (whether legislative, executive, administrative, judicial, contractual or consensual) or conduct that is otherwise not covered by established legal defenses or relevant principles under domestic law." 250

Regardless of what the drafters wished to exclude from the ambit of the application of the Convention, the inclusion of the qualifier "unlawfully" has left a gap in the Convention that is open to different interpretations. In

245. Lavalle, supra note 169 , at 500.

246. U.N. Doc. A/C.6/54/L.2, supra note Io, Informal summary of the discussions in the Working Group, prepared by the Chairman, 967 .

247. U.N. Doc. A/54/37, supra note 9, Annex IV, ๆ I7.

248. Aust, supra note 20, at 294.

249. U.N. High Commissioner, Comments by the United Nations High Commissioner for Refuges on the draft international convention for the suppression of the financing of terrorism, $\mathrm{U}$. N. Doc. A/C.6/54/WG.I/INF/I (Nov. 9, 1999) 4. See also U.N. Observer of the International Committee of the Red Cross, Replies given on 22 March 1999 by the observer of the International Committee of the Red Cross to the questions asked by the delegations of Belgium and Mexico regarding the implications of article 2, paragraph I(b), U.N. Doc. A/ AC.252/1999/INF/2 (Mar. 26, 1999).

250. Lehto, supra note 99, at 266, refers to the reason provided by the Council of Europe for the retention of the expression "unlawfully" in the criminalization of terrorist offenses. See Explanatory Report to the Council of Europe Convention on the Prevention of Terrorism (2005, CETS No.I96), ๆ 82, https://rm.coe.int/1680od38II. 
fact, the insurmountable difficulty that the drafters faced in introducing the new offense of terrorist financing was how to define "terrorism" distinguishable from the acts committed by freedom fighters in furtherance of a struggle against oppression and foreign occupation. ${ }^{251}$ As mentioned earlier, all attempts in this respect failed because the drafters could not adequately outline the contours of terrorism and terrorist acts; they also avoided defining "terrorist group." In such uncertain and controversial circumstances, it is not surprising that the term "unlawfully" can be used as a "shorthand reference to grounds excluding" the financing of acts and groups that a State does not wish to label "terrorist and unlawful." 252 For example, Switzerland 253 and Austria ${ }^{254}$ introduce an exclusion of criminality for an act of financing directed to the establishment or reestablishment of a democratic and constitutional regime or to the exercise or protection of human rights. ${ }^{255}$ However, how and on what basis the legitimacy of people who resort to violence to establish a democratic situation or protect human rights should be determined may vary from one State to another, depending whose side a State would be on (the current civil law is Syria is a good example).

In the absence of clarity and consensus on whether (or how) "terrorism" includes a situation of armed conflict, the inclusion of the qualifier "unlawfulness" gives rise to controversy over whether the terrorist financing offense includes cases where the financing is carried out for the support of situations involving armed conflict. It seems that countries are confronted with dilemmas. Some States, such as Switzerland, may not regard an act of financing as unlawful "if with the financing, acts are to be supported that are not in contradiction with the rules of international law pertaining to armed conflicts." ${ }^{256}$ Other States, such as New Zealand, ${ }^{257}$ may favor broadening the meaning of "terrorism" to include

25I. U.N. Doc. A/C.6/54/L.2, supra note Io, Annex III, ๆ

252. Lavalle, supra note I69, at 501.

253. Swiss Criminal Code, Art. 260 quinquies(3).

254. Austrian Criminal Code, Art. 278c(3).

255. It is worth noting that Greece, in Art. I87A (8) of its Penal Code, had included a similar exception, but it removed the exception in order to meet the FATF requirements. See FATF, Mutual Evaluation Report of Greece: Follow-up Report, 9 6o (Oct. 28, 20II).

256. Mark Pieth, Criminalization of the financing of terrorism, 4(5) J. INT'L CRIM. JUST. IO8I (2006).

257. Terrorism Suppression Act 2002, §§ 5(I)(c), 4(I) (N.Z.). 
any activities that occur in a situation of armed conflict, and whose purpose is to cause death and bodily injury to a civilian, and to intimidate a population or to compel a government to do or prevent from doing an act. In such a case, counterterrorist financing laws can be applied to the financing of armed groups involved in a situation of armed conflict, including freedom fighters.

\section{The link between acts of financing and terrorist acts}

One of the main challenges that the drafters faced was how to outline the scope of the new offense so that it could not to be understood or interpreted as a preparatory offense to terrorism. To do so, the drafters had to clearly define the connection between acts of financing and a terrorist act. Under the initial draft of the Convention, the offense was defined to include "the financing of a person or group of persons" who "commits or proposes to commit" an offense annexed to the Convention or a terrorist act defined by the Convention. ${ }^{258}$ Although the language of this definition, which refers to the commission of subsequent terrorist acts, seemed to suggest that the act of financing need be related to a specific act, it was argued that there should be no need for the establishing of a precise connection between particular funds provided to terrorists and a specific act, because most of the funds given to terrorists are spent on long-term preparations that are not directly related to a particular attack. ${ }^{259}$ It was also pointed out that, although it can be possible to trace the providers of a physical item used in the commission of a terrorist act, it would be very hard (if not impossible) to trace and prove that a specific amount of funds or money have been used to facilitate or finance the commission of a particular terrorist attack.

On the other hand, those delegations that tried to limit the scope of the offense to the financing of an organization, found this reasoning inapplicable to the case of the financing of individuals. ${ }^{260}$ They argued that, whereas the independent criminalization of the financing of groups, which have the elements of "long-term planning, continuity of purpose, division of labour and particular difficulty of detection," is justifiable, the financing

258. Permanent Rep. of France to the U.N., supra note 6, Art. 2.

259. Aust, supra note 20, at 296-97.

26o. U.N. Doc. A/AC.252/1999/WP.I2, reproduced in U.N. Doc. A/54/37, supra note 9, at 3I. 
of an individual in order to enable that individual to commit a crime would merely constitute a preparatory offense under national and international law. As mentioned earlier, this reservation was not taken into account, as the draft sponsors wished the offense to have a broader scope.

After failure to define "terrorist group," the drafters deleted the references to both a person and an organization. The Convention was reformulated with a direct reference to terrorist acts, which do not necessarily need to be committed or attempted; that is, the Convention requires the criminalization of the collection or provision of funds with the intention that the funds should be used or in the knowledge that they are to be used, in full or in part, to commit "an act" annexed to the Convention or "any other act" that matches the definition of terrorism provided in Article 2(I). To make sure that the scope of Article 2 could expand to include the financing of any and all terrorist-related offenses, the draft sponsor, France, suggested that "in order to convict a person for an offence [defined by the Convention] it shall not be necessary to prove that the funds were in fact used to prepare for or to commit a specific offence." ${ }^{261}$ Therefore, it does not matter how remote the act of collection or provision of funds is from the actual commission of subsequent terrorist offences. What is important for an act to be considered as a terrorist financing offense is the mental element: that the collected or provided funds "should be" or "are to be used" for terrorist purposes. This will be discussed in detail in the next section.

As a result of the inclusion of this paragraph, the proposal — which tried to restrict the scope of the offense to the financing of the terrorist acts, which constitutes "main" offenses within the scope of the conventions listed to the Annex-did not find its way into the final draft. ${ }^{262}$ According to this proposal, "main offence means any offence within the scope of one of the Conventions set forth in the Annex excluding attempts and contributory or participatory offences." In the proposer's view, criminalization of mere preparatory acts (e.g., contribution to, or facilitation of, an attempt to commit a terrorist act) would create "the danger of very long chains of participation removing a reasonably close nexus to the main offence; the scope of application would become too large."

26I. U.N. Doc. A/54/37, supra note 9, Annex I, Art. 2(2).

262. U.N., Doc. A/AC.252/1999/WP.I2 reproduced reprinted in U.N. Doc. A/54/37, supra note 9 , at $3 \mathrm{I}$. 
However, in practice, controversy still exists about how the preparatory act of financing a specific terrorist offense or the financing of an individual who is to commit a particular attack can be classified as an independent offense. In practice, some countries resist criminalizing the financing of a specific act as an independent offense (probably because of its inconsistency with their domestic law). For instance, "if the financing of terrorism is related to a specific crime, Denmark's approach to criminalization ... is through a person's complicity in the terrorism offence" pursuant to Section II4 (terrorism offences) and Section 23 (complicity) of the Danish Criminal Code. ${ }^{263}$ Similarly, in Germany, the financing of terrorist acts and financing of individual terrorists may be prosecuted based on the participatory offense of "assisting another to commit a crime."264

Perhaps the main concern lies in the fact that the application of the Convention to the financing of a specific act results in over-criminalization. For example, if someone provides his car to terrorists with the intention that it should be used or with the knowledge that it is to be used in a car bomb attack at a specific place and at a certain time ${ }^{265}$ the car provider, according to the Terrorist Financing Convention, is to be charged with the primary offense of terrorist financing. The car provider can be also convicted of another ancillary offense under Article 2(3) of the Terrorist Bombing Convention. Although the Convention is silent on this issue, and national attempts vary with regard to the issue of multiple convictions, ${ }^{266}$ the FATF insists that criminalizing terrorist financing as complicit in a terrorist's act is not sufficient to meet its requirements. In spite of the FATF's recommendations, and to avoid multiple convictions, suspects in Finland ${ }^{267}$ and Sweden ${ }^{268}$ are

263. FATF, Third mutual evaluation on anti-money laundering and combating the financing of terrorism: Kingdom of Denmark, 9216 (June 22, 2006). See also FATF, Mutual evaluation on anti-money laundering and combating the financing of terrorism: Kingdom of Denmark: 3 rd Follow-up Report, (Oct. 22, 2010).

264. International Monetary Fund, supra note 217, ๆ 210.

265. Lavalle, supra note I69, at 50I.

266. For more info about national and international debates on multiple convictions, see Prosecutor v. Zejnil DELALIC, Zdravko MUCIC, Case No. IT-96-2I-A, Appeals Chamber, \\ 4I5-I2 (Int'l Crim. Trib. for the Former Yugoslavia, Feb. 20, 200I).

267. FATF, Third mutual evaluation on anti-money laundering and combating the financing of terrorism: Finland, $1 \mathrm{I} 53$ (Oct. I2, 2007). See also FATF, Mutual evaluation of Finland: 9th Follow-up Report (June 20I3).

268. Section 5 of the Act on Criminal Responsibility for the Financing of Particularly Serious Crime, in some cases (2002:444) (Swed.). 
not prosecuted for the terrorist financing offense if the act is punishable as the commission or attempted commission of terrorist offenses covered by their Penal Code, or offenses for which a severe sentence is provided elsewhere in the law.

\section{Key role of the subjective element in the construction of the new offense}

The final formulation of the offense in which no causality between the act of financing and subsequent terrorist acts needs to be established raised the question of what a financer should have known or intended in order to have committed the crime of terrorist financing. Under the working document submitted by France, a person commits a crime if that person intentionally proceeds with the financing of a person or a group in the knowledge that such financing "will or could be used, in full or in part, in order to prepare or commit" terrorist acts. ${ }^{269}$

However, the inclusion of the expression "could be used" was criticized mainly for its vagueness. It was argued that the acts of financing should be criminalized only if the funds "provided" are likely to be used for the commission of terrorist acts. "The language 'or could be used' covers all possibilities of a use of the assets or property for terrorist activities and leaves too much room for interpretation." 270

A suggestion was made to lower the mens rea standard to recklessness, requiring the criminalization of the provision of funds where "there is a reasonable likelihood that the funds will be used for" the preparation or commission of terrorist offenses. ${ }^{271}$

Another proposal was put forward by a group of several delegations (Austria, Belgium, Japan, Sweden, and Switzerland), which tried to limit the scope of the criminalization to financing that was not remote from the act of terrorism. According to their proposal,

Any person commits an offence within the meaning of this Convention if that person unlawfully and intentionally provides funds, directly or indirectly and however acquired, to any person or organization committing or attempting to commit:

269. U.N. Doc. A/54/37, supra note 9, Annex II, Art. 2(I). See Lehto, supra note 99, at 274-75.

270. U.N. Doc. A/AC.252/1999/WP.26 and U.N. Doc. A/AC.252/1999/WP.I2, reproduced in U.N. Doc. A/54/37, supra note 9 , at $3 \mathrm{I}$.

27I. U.N. Doc. A/AC.252/1999/WP.20, reproduced in U.N. Doc. A/54/37, id. at 34 . 
a) Any offence within the scope of the one of the Convention listed in the Annex $\cdots$

Such financing shall [either] be made with the intention that the funds be used [or in the knowledge that the funds are to be used], in whole or in part, for the commission of the offences mentioned above. ${ }^{272}$

The proposal sponsors explained that "the inclusion of the term 'or attempting to commit' [in this definition] is subject to the deletion of any reference to attempts and participatory offences under the scope of the Convention listed in the annex." 273 In fact, the proposers tried to introduce a filter in the definition that would exclude from the ambit of the Convention the financing of an attempt of the offenses listed in the Annex because they had doubts about whether a contribution to an act that constitutes complicity in those conventions and that would be too far remote from its subsequent act could be independently criminalized in any jurisdictions. The language "committing or attempting to commit" also implied that the financer had to be aware of the material causality between his or her provision of the funds and an attempted or committed act.

None of these proposals were taken into account as they seemed to emphasize the knowledge and intention of the financer in relation to the preparation or commission of a specific terrorist act. This would have restricted the scope of the new offense to an act of complicity, which was not what the draft sponsors wished. In other words, from the drafter's perspective, any reference to the attempt or commission of a subsequent terrorist act, or inclusion of any qualifier that excludes from the scope of the Convention the financing of particular terrorist acts, ${ }^{274}$ including the financing of attempts and participatory offenses as proposed, might have endangered the effectiveness of the Convention. This is because it could

272. U.N. Doc. A/AC.252/1999/WP.49, reproduced in U.N. Doc. A/54/37, id. at 5I.

273. Id. See also LeHTO, supra note 99, at 277.

274. Lehto, supra note 99, at 277. During the negotiation, a proposal was made to exclude from the ambit of the Convention the financing of offenses listed in the Annex, and that are not "serious." According to this proposal, the scope of the Convention should not be expanded to include "trivial offences." This proposal was rejected for the same reason as mentioned: any qualifier such as this would have required courts to find a link between the act of financing and a terrorist act attempted or accomplished. See U.N. Doc. A/C.6/54/L.2, supra note Io, Informal summary of the discussions in the Working Group, prepared by the Chairman, ๆ 7I. 
have required the prosecution to infer the knowledge or intention of a financer in regard to the specific act for which the funds have been collected or provided.

As a result, the drafter decided to reformulate the definition in Article 2(I) to be read as follows:

Any person commits an offence within the meaning of this Convention if that person by any means, directly or indirectly, unlawfully and wilfully, provides or collects funds with the intention that they should be used or in the knowledge that they are to be used, in full or in part, in order to carry out:

a) An act which constitutes an offence... defined in one of the treaties listed in the Annex; or

b) Any other act intended to cause death or serious bodily injury to a civilian, or to any other person not taking an active part in the hostilities in a situation of armed conflict, when the purpose of such act, by its nature or context, is to intimidate a population, or to compel a government or an international organization to do or to abstain from doing any act.

Paragraph 3 was added to Article 2 to emphasize that "for an act to constitute an offence set forth in paragraph I, it shall not be necessary that the funds were actually used to carry out an offence referred to in paragraph I, subparagraphs (a) or (b)." As a result, the inclusion of paragraphs 4 and 5 in Article 2 was accepted without any argument. These provisions criminalize any attempt to finance, including secondary participants, those organizing and directing others to commit terrorist financing, and conspiracies to commit terrorist financing. The inclusion of these provisions extends the scope of the criminalization to conduct that is remote even from the act of financing, regardless of whether the funds are used for a subsequent terrorist act and regardless of whether a subsequent act is committed or merely planned.

In short, what makes the act of financing an offense is not the criminal or terrorist nature of the act, but the malicious intent of the financer. With the inclusion of Paragraph 3, the fault element of the crime acquires a "hypothetical" nature, as the financer who does not know about an actual terrorist act should assume or admit that that the recipient will use the funds collected or provided to further a terrorist cause. Under such a formulation, in a similar way to U.K. and Canadian law, ${ }^{275}$ it 
would be more precise to speak of the financing of "terrorist purposes" or "terrorist activities." 276

This conception of the offense in which the intention or the knowledge of the financer is referred to (but not relied on) future conduct or a possible harm is groundbreaking in the law on terrorist offenses. ${ }^{277}$ Whereas all of the prior terrorist-related conventions target harmful and stand-alone offenses such as murder, kidnapping, or destruction of and severe damage to property, and require a fault element that is specified in relation to the physical elements of these offenses, the Terrorist Financing Convention criminalizes victimless, nonviolent, and preparatory acts or illegal (but nonterrorist) conduct (where funds are derived from illegal sources) only on the basis of the terrorist purposes that a financer may have.

The criminalization of terrorist financing as an independent, standalone offense extends the scope of criminal law in a way not previously done. Traditionally, the law has incriminated preparatory acts through the extension of criminal liability to accessorial liability. Accessorial liability has a derivative nature in the sense that the prosecution should prove that the substantive offense has been committed or least attempted. ${ }^{278}$ Under a new approach pursued by some common law jurisdictions, the scope of inchoate crimes has been extended to include "encouraging and assisting" offense(s) that "will be committed." ${ }^{279}$ It is clear that this offense applies irrespective of whether the substantive or anticipated offense(s) are or actually will be carried out by the principal offender. The inchoate offender in these offenses must believe, without any significant doubt, that the principal offender will commit the anticipated offense(s) with the relevant intent element. ${ }^{280}$ The inchoate offender must also believe that any circumstances or consequences specified in the anticipated offense(s) will be fulfilled. Therefore, the prosecution must specify the offenses that the inchoate offender's act might have assisted or encouraged. ${ }^{281}$ In contrast,

276. Lehto, supra note 99, at 263.

277. Id. at 269.

278. Bernadette McSherry, Expanding the boundaries of inchoate crimes: The growing reliance on preparatory offences, in Regulating DeVIANCE: THE REDIRECTION OF CRIMINALISATION AND THE FUTURES OF CRIMINAL LAW I4I-64, I42 (Bernadette McSherry, Alan Norrie, \& Simon Bronitt eds., 2008).

279. Serious Crime Act 2007, §§ 44-47 (U.K.).

280. Andrew Ashworth, Principles of criminal law 460-6i (6th ed., 2009). 28r. Id. 
the terrorist financing offense need not be proved in relation to any specific or subsequent terrorist crime. The only relevant offense here, as some argue, is a "fictional crime" that the financer assumes or admits that the recipient of the funds will commit. ${ }^{282}$

6. Can this formulation be justified on the basis of analogy with remote harms?

Generally speaking, the autonomous criminalization of preparatory acts, including terrorist financing, should be considered in the context of the shift toward "preventive" approach, ${ }^{283}$ where "the post-crime orientation of criminal justice is increasingly overshadowed by the pre-crime logic of security." 284 Under this approach, States are licensed to criminalize "abstract endangerment" acts that pose the risk of certain harms. ${ }^{285}$ These acts are criminalized not because they are "wrongful or harmful" in themselves, but because they create an opportunity for the commission of future danger. ${ }^{286}$ The typical examples of these acts are possession offenses: possession of weapons, ${ }^{287}$ of illegal drugs, ${ }^{288}$, and of burglary instruments. ${ }^{289}$ Unlike inchoate offenses, conviction for these offenses does not necessitate proof of intent to commit any subsequent crime. Instead, the prosecution simply needs to prove that the offender has been aware of the possession "under suspicious circumstances." 290 The justifiability of criminalizing these types of offenses is, however, questioned. It is argued that these offenses "may criminalize people at a point too remote from the ultimate harm, not allowing for a change of mind." 291 It is also pointed out that possession offenses extend the scope of criminal law beyond the inchoate

282. Lehto, supra note 99, at 287.

283. See Carol S. Steiker, The limits of the preventive state, 88(3) J. Crim. L. \& CRImINOLOGY 77I (1988).

284. Lucia Zedner, Pre-crime and post-criminology, 2(II) Theoretical Criminology 263 (2007).

285. A.P. Simester \& Andrew Von Hirsch, Crimes, harms, and wrongs: On the PRINCIPLES OF CRIMINALISATION 57 (2OII).

286. Ashworth, supra note $28 \mathrm{o}$, at 38 .

287. See, e.g., Prevention of Crime Act 1953 (U.K.).

288. Misuse of Drugs Acts 1977, § 5(2) (U.K.); or Criminal Code $\S 88$ (Can.).

289. Theft Act I968, § 25 (U.K.).

290. Christopher Slobogin, A jurisprudence of dangerousness, 98(I) Nw U.L. REV. 56 (2003). 29I. AshwORTH, supra note 280, at 97. 
crimes, sweeping too wide in the sense that " $t]$ hey encompass cases where there is no potential social harm."292

Regardless of whether the criminalization of remote harms is justifiable, it seems that there are substantial differences between these offenses and the terrorist financing offense introduced by the Convention in terms of risks that flow from them, objects involved, and circumstances within which these offenses are carried out. Although the risk in many of the remote harm offenses is more visible and immediate-a risk that is either explicit (e.g., dangerous driving) or implicit (e.g., speeding) ${ }^{293}$ — the risk of harms in the terrorist financing offense is even more remote. Indeed, it is far too remote and "fictional" as the financer need only assume or admit that the funds collected or provided will be used (by the financer or others) for terrorist purposes. Terrorist financing is more similar to the rare cases when a State, for example, prohibits certain public demonstrations because of what they may prompt others to do in response.

In regard to objects and circumstances, whereas the criminality of remote harm offenses is, in most cases, reliant either on the illegal nature of the object possessed (e.g., possession of controlled drugs or unregistered possession of a firearms or explosives), or on the circumstances within which the object is being used (e.g., possession of tools for use in a burglary at the place other than the abode of the possessor), ${ }^{294}$ terrorist financing includes material assistance or financial contributions that, in most cases, have a legal appearance (fundraising or the transfer of the funds collected to middlemen). Even if the financing involves illegal transactions such as purchase of explosives, although the criminal intention of the offender can be easily related to the illegal circumstance that the offender is involved in, the proof of the intention or knowledge of the offender in relation to terrorism or a terrorist act seems difficult (if not impossible) and, furthermore, according to the Convention, unnecessary.

Moreover, unlike remote harm offenses in which the fault element is the intent in relation to the act that the offender carries out, and not to its eventual harmful consequences, the fault element in terrorist financing cannot be merely an intent to perform acts of financing, because such acts, in themselves, do not have a terrorist nature, especially when all that

292. George P. Fletcher, Basic concepts of Criminal law i76 (I998).

293. Ashworth, supra note 280 , at 38 .

294. Theft Act 1968, § 25(I) (U.K.). 
is involved is the collection of funds or the transfer of the funds collected to middlemen.

\section{EXAMINATION OF THE FAULT ELEMENTS OF THE OFFENSE OF TERRORIST FINANCING}

The questions that the drafters left unanswered are, If there is no need to link the acts of financing to any subsequent terrorist act, and if financing alone can hardly provide a solid basis for prosecution or conviction, what must the financer know to be held criminally responsible? How should the intention be read when the act of the financer is far removed from any subsequent act? And what is the particular context or circumstances of the offense of terrorist financing?

Although the Convention is not clear on these matters, the answers to these questions seem to be very critical as all other elements of the offense are heavily reliant on the fault element:

I. Although financing is the basic element of an offense in the inchoate mode (collection or provision of funds with intent to supply terrorism), the drafters established an independent offense of terrorist financing by putting so much weight upon the fault element: financing with the intention or in the knowledge that the funds collected or provided will be used for commission of a terrorist act. The Convention does not even differentiate between the act of provision and the act of collection, which seems (at least in some cases) to be a prerequisite to the act of provision; that is, as long as an act, either collection or provision, is involved in the idea of terrorism, it falls into the category of the offense.

2. The term "funds" has been defined very broadly to cover any contributions (with or without legal origin) that are intended or known to be used for terrorist purposes.

3. The Convention requires the criminalization of financing of an attempt and of an attempt to finance that are carried out with terrorist intent, although they are very remote from a possible subsequent act and although their criminalization extends the scope of criminal liability beyond the law of attempts.

Drawing on member States' legislation on terrorist financing and cases, this section examines whether the fault element of an independent offense of 
terrorist financing can be adequately defined, and whether such criminalization can be justified using traditional justifications for criminalization.

To clarify the issue, it would be better to test the fault element in the circumstances within which financing may take place. In reality and regarding the current counterterrorism regime, two scenarios can be envisaged: (I) when the financing is carried out for the preparation or commission of a terrorist act; and (2) the financing of a group or a person who is designated as terrorist, or is involved or has been involved in terrorist activities.

\section{A. Financing a Terrorist Act}

This scenario includes the situation in which a financer is involved in the collection or provision of funds known or intended to be used for the preparation or commission of a terrorist act. The main question here is whether, in the absence of a requirement to link the financer's conduct with a terrorist act, the imposition of guilt on the financer is justifiable and compatible with the basic principles that underlie the criminal law. According to the Convention, the financer acquires independent criminal liability (similar to terrorism) for conduct that is no more than preparatory to the intended commission of the subsequent offense. Whereas many features of this situation are similar to an inchoate offense or complicity, the common argument put forward in justification of this approach is that the criminalization of such an act as an inchoate crime may not secure the conviction sought since, "in most jurisdictions, aiding and abetting occurs only when the alleged perpetrator has knowledge that the principal offense is being committed or at least attempted."295

Three objections to criminalizing the financing of a terrorist act as an independent offense, however, stand out. One is that normal principles seem not to support such liability: if financing carried out to support the commission of a particular offense is independently criminalized without the requirement to prove the financer knew of or intended to fund a specific violent act, the occurrence of which depends on a further decision by the financer or by another, such an intervening voluntary act might relieve the original actor of the subsequent offense of criminal responsibility, and so it

295. International Monetary Fund, Suppressing the financing of terrorism: A handbook for legislative drafting (2003), http://www.imf.org/external/pubs/nft/2003/sfth/. See also KoH, supra note 79, at 66 . 
is the financer who should be punished. If the financer is to perform the subsequent offense, such an approach does not treat the financer as an independent agent capable of deciding to abandon his criminal enterprise.

This also brings up the potential for injustice. The fault element of the financer should not be inferred with regard to the putative offense for which the financing has been carried out because the commission of the subsequent crime may not be necessarily the result of the financing. But under the Convention, any contribution seems to suffice for liability, no matter how small and no matter whether the contribution has any impact on the commission of the subsequent offense. ${ }^{296}$ Therefore, financers in both minor and major cases of financing incur the same liability and are subject to the same punishment. Such an approach is not acceptable to some jurisdictions. For example, in spite of the FATF's criticism, ${ }^{297}$ in Germany, "insubstantial" contribution to the commission of a violent act is outside the scope of the offense of terrorist financing even if it is collected or provided with the intent to be used for a terrorist act.

Finally, the criminalization of the financing of a terrorist act leads to confusion about the further fault element that should be proved. If financing can be criminalized without any need to prove its connection to the subsequent offense for which the financing has been carried out, what state of mind should be shown in order to hold the financier criminally responsible? If the Convention should be read to mean that the collection or provision of funds should be carried out only for terrorist purposes, what, then, amounts to terrorist purposes or terrorist intent? Is terrorist intent definable? Does terrorist intent mean the objectives of terrorist acts defined by the Convention: intimidating population or compelling a government or an intentional organization to do or to abstain from doing an act? That is, must a financer have known or intended that the funds collected or provided to be used to bring about these purposes?

\section{Is "terrorist intent" adequate as the mental element?}

Regarding the fact that there is no consensus on the definition and elements of terrorism, it seems that such a reading of the Convention may give rise to

296. The Convention does not differentiate between minor or major cases of terrorist financing.

297. FATF, Mutual evaluation report: Anti-money laundering and combating the financing of terrorism: Germany, I 210 (Feb. I9, 20IO). 
the absence of a harmonized implementation of the Convention. In this regard, national attempts to come to grips with the fault element have proven that defining "terrorist intent" can be controversial. For example, Germany, in implementing the Convention, criminalizes the collection or provision of funds carried out with the intent to fund a serious violent act "endangering the state." "Endangering the state" is defined as "an offence against life ... or against personal freedom ... which under the circumstances, is intended to impair [or is] capable of impairing the existence or security of a state or of an international organisation, or to abolish, rob of legal effect or undermine constitutional principles of the Federal Republic of Germany." 298 As can be seen, the serious violent act "endangering the state" is narrower in scope than the definition of "terrorist act" introduced by the Convention as it does not cover the objective of "intimidation of population."

Other jurisdictions have introduced explicit criteria that exclude from their implementation of the obligation in the Convention the financing of violent acts carried out for certain particular purposes. Switzerland, for instance, does not consider the financing of a violent act as a terrorist financing offense if the financing has been carried out with the intention to establish or re-establish a democratic regime or a State governed by the rule of law, or with the intention to exercise or safeguard human rights. ${ }^{299}$ Although it is not very clear how human rights or democratic values can be restored by resorting to violence, imposing such requirements is not beyond expectation when the scope of the offense of terrorism has not been (cannot be) defined.

Regardless of what constitutes terrorist intent and how such intent could be inferred, courts in some jurisdictions do not require the proof of terrorist intent as an essential element of preparatory terrorism offenses, including the terrorist financing offense, at all. For example, an Australian court held that it is not necessary to prove that the defendant, who was accused of possessing things connected with preparation for, the engagement of a person in, or assistance in a violent act, had terrorist intent. ${ }^{300}$ That is, the prosecution did not need to prove that the defendant carried out the conduct that he was accused of with the intent to further a political, religious, or ideological cause; and with the intent to coerce, influence by intimidation,

298. German Criminal Law $\S 89 a(\mathrm{I})$.

299. Swiss Criminal Law. Art. 260 quinquies(3).

30o. Lodhi v. The Queen (2007), I79 A Crim R 470, ๆ 9I (Austl.). 
a State, Territory, or Commonwealth government, or to intimidate the public or a section of a public. ${ }^{301}$ The Court reasoned that a defendant might not have any interest in accomplishing any of these purposes, but he might, for instance, be simply plying his trade, or doing a favor for an acquaintance, or repaying a debt. ${ }^{302}$

But what then of the intent requirement as the connection between the act of financing and the subsequent violent act? Here, again, problems may arise with interpretation.

2. So, what is the mental element for terrorist financing?

Generally, the mental element of a crime can be determined in relation to the physical elements of that crime. Physical elements, in general, can be divided into three parts: the individual's conduct, the consequences of that conduct, and the circumstances in which the conduct has occurred. ${ }^{303}$ The Rome Statute, as Lehto argues, illustrates how the fault element can be demonstrated with respect to each material element of a crime. Setting out the requirements of knowledge and intention for the purposes of creating criminal liability, Article 30 of the Rome Statute provides that "a person has intent where (a) in relation to conduct, that person means to engage in the conduct, and (b) in relation to a consequence, that person means to cause that consequence." Similarly, knowledge only exists where the person is aware that "a circumstance exists or a consequence will occur in the ordinary course of events."

Similar to the Rome Statute, the mental element of the offense set out by the Convention consists of two main variants: intention that funds will be used to carry out a terrorist act, and knowledge that the funds are to be so used. However, it is often impossible to presume the intent from the physical act of financing as the conduct element of the offense consists of acts that are innocent in themselves (especially when the funds have a legal origin, and the charge is that of collecting), or acts that may have a criminal but non-terrorist nature.

In addition, intention in the sense of the desire to bring about a certain consequence or knowledge of consequences seems to have a "hypothetical

30I. Australian Criminal Code $\S$ Ioo.I.

302. R v. Lodhi (2006), NSWSC 468 (Austl.), reprinted in McSherry, supra note 278. 303. Lehto, supra note 99, at 285. 
quality" 304 when it comes to the crime of financing of a terrorist act. According to the Paragraph 3 of Article 2, it is not necessary that funds are used to carry out a terrorist act. If this provision has any meaning at all, this must indicate that intention or knowledge does not have to linked to the terrorist act for which the funds are collected or provided; that is, the enduse of funds is irrelevant, it is what the financer thinks the end-use is that is relevant. The point is that if a specific (subsequent) violent offense was required to be intended or known, it would limit the crime of financing to the equivalent of an act of complicity or attempted offenses. ${ }^{305}$ Intending to create an independent crime of financing, the drafters of the Convention seem to be successful in defining what does not constitute the intent of the offense. It seems this is the case for all preparatory terrorism acts- "the financing, planning, preparation or preparation of terrorist acts"-which should be treated "as serious criminal offences" even in the absence of a subsequent violent act or where there is no connection between these offenses and a specific violent act. ${ }^{306}$ But at national levels, this seems to lead to confusion and controversy over the intent that must be proved.

\section{Can awareness of a circumstance be the mental element? $R$ v. Lodhi}

Awareness of a circumstance was regarded as a sufficient ground for imposing liability by the court in an Australian ${ }^{307}$ case where the court tried to

304. Id. at 283 .

305. Id.

306. The U.N. Security Council, in Res. I373 (200I) § 2(e), includes a provision declaring that all States should "[e]nsure that any person who participates in the financing, planning, preparation or perpetration of terrorist acts or in supporting terrorist acts is brought to justice and ensure that, in addition to any other measures against them, such terrorist acts are established as serious criminal offences in domestic laws and regulations and that the punishment duly reflects the seriousness of such terrorist acts."

307. In Secs. IOI-IO3 of its Criminal Code, Australia has introduced a broad range of ancillary terrorism offenses ("possessing things connected with terrorist acts"; "collecting or making documents likely to facilitate terrorist acts"; "collecting or making documents likely to facilitate terrorist acts"; "other acts done in preparation for, or planning, terrorist acts"; and terrorist financing). As the definition of funds under Section IOI.I is an expansive definition that includes various objects, and as the language of other terrorism-related sections - particularly phrases such as "things" or "document"-is very broad, these offenses can capture many forms of financing of terrorism. But what all these provisions have in common is that they fail to draw a clear connection between the person who collects materials and the subsequent offenses for which the materials are collected. 
determine the necessary fault element for independent preparatory terrorism offenses. Lodhi was accused of three offenses: purchasing two maps of the Australian electricity supply system in preparation for a terrorist act; possessing information regarding the ingredients for and the method of manufacture of explosives in preparation for a terrorist act; and seeking a price list of chemicals for the use of explosives for a terrorist act. ${ }^{308}$

The accused explained that his collection of the maps had nothing to do with any terrorist act or part of any plan to execute a terrorist act against the Electricity Supply System. ${ }^{309}$ He explained he simply wanted them for a company of an electrical nature he was planning to establish. He gave similar explanation for the seeking a price list of chemicals. He stated that he was proposing to set up a business venture to export certain chemicals from Australia. ${ }^{310}$ Regarding the possession of the materials containing information about making explosives, he gave evidence that many years earlier, he had seen them on a computer when he was studying some architectural subjects at the University of Sydney. ${ }^{311}$

Relying on circumstantial evidence, the prosecution alleged that Lodhi intended to "advance the cause of violent jihad and intimidate the government and the public" by plotting to bomb part of Sydney's electrical supply system. ${ }^{312}$ The prosecution referred to DVDs and CDs of jihadist doctrine that were found in his house. The prosecution argued that the possession of this material by the defendant exposed his malicious intention with regard to these offenses. ${ }^{313}$ The prosecution also alleged that Lodhi was in contact with a French terror suspect while he was in Sydney.

Lodhi explained that he had not seen this jihadi material, so he could not explain its presence at his home. ${ }^{314} \mathrm{He}$ admitted the existence of other material containing exhortations to violent jihad, but he explained that "he had either not seen it or, if he had seen it, it was only in part and that he had generally little to do with the contents." 315 Regarding the association with the French suspect, Lodhi admitted that he was in contact with the French

308. R v. Lodhi (2006), 199 FCR 364 (Whealy J.) (Austl.).

309. Id. $\mathrm{I} \mathrm{I}$.

3IO. Id. ๆ 30.

3II. Id. 9 4I.

312. Id. $9 \mathrm{I} 7$.

3I3. Id. ๆ $\mathrm{I} 8$.

3I4. Id. ๆ 19.

3I5. Id. \ 19. 
suspect, but he stated that he did so as a courtesy and favor to a foreigner visiting a new country at the behest of a mutual friend. ${ }^{316}$

The Lodhi court provided a test case for the provisions on preparatory terrorism offenses that do not fall into a clear definition of the fault element in relation to the physical element of these offenses. The court needed to examine the criminal intent of the accused in the absence of the subsequent offense for which the preparatory acts were carried. But the court struggled to come to a decision.

The court stressed that

an evaluation of the criminal culpability involved in any particular offence requires an analysis not only of the act itself, which may be relatively innocuous, but as well an examination of the nature of the terrorist act contemplated, particularly in the light of the intentions or state of mind of the person found to have committed the offence. ${ }^{317}$

However, it read the offense as not requiring the prosecution to prove that the accused intended to facilitate either a specific terrorist act or general terrorist activity. The judge said that such offenses "will have been committed by a person in a preliminary way ... even where no final decision has been made over the final target" 318 _ which means knowledge of a target is not needed.

The main question is how the court could have inferred the terrorist nature of such preparatory acts without requiring the prosecution to prove that the accused intended to bring about the subsequent offense. The court's rulings do not seem to be consistent. On the one hand, the court was satisfied "beyond reasonable doubt, at the forefront of the offender's mind when he collected the maps, that he had not at that stage necessarily made a final determination as to the precise target, or the precise area of the target, that was to be hit."319 The court held that

the maps themselves would not have given sufficient information to the offender. Nor would they, of themselves, have given sufficient insight into how such an attack upon the electrical system could be maintained at a time when the actor has not decided precisely what he or she intends to do, an offence. ${ }^{320}$

\footnotetext{
316. Id.

317. Id. ๆ 5.I.

3I8. Reprinted in McSherry, supra note 278, at I49.

319. Lodhi, supra note 300, ๆ 21.

320. Lodhi, supra note 300, \20.
} 
So the court concluded that it was "not satisfied beyond reasonable doubtthat the offender had at any time made up his mind that it would be he who would carry out the bombing of the Australian Electrical Supply System." ${ }^{21}$ In the same way, it concluded that although the accused possessed a formula for making a bomb, there was no evidence to suggest that the offender ever intended that there would be an enterprise involving the use of the formula aimed at any person, or for that matter, any property. ${ }^{322}$

On the other hand, the court ruled that it was not important that the existing evidence could not demonstrate that Lodhi had ascertained and decided "when, how, where or by whom a terrorist act might be carried out." 323 The court found that the accused was aware of the circumstances in which the preparatory acts occurred. That is, the accused knew that there was, "in the circumstances of all three offences, really one continuing uninterrupted course of conduct centring upon an enterprise to blow up a building or infrastructure." 324 In spite of the fact that the document containing information on how to make explosives was collected a long time before the accused bought the maps and asked for the price list of chemicals, the court concluded that the contents of the document considerably fleshed out the accused's intention in relation to the circumstances surrounding the obtaining of the maps and the enquiries he made of the chemical supply company. ${ }^{325}$

In addition, the court, without explanation, considered the accused's contact with the French suspect as a relevant matter to the existence of these intentions without clarifying what the French suspect's role was to be with regard to any terrorist act. ${ }^{326}$ Similarly, the court found the accused's possession of the "Jihadi CD" relevant, stating that the "truth is that all this material makes it clear that the offender is a person who has, in recent years, been essentially informed by the concept of violent jihad and the glorification of Muslim heroes who have fought and died for jihad, either in a local or broader context." 327 It stated that "the [Jihadi] material is eloquent as to the ideas and emotions that must have been foremost in the offender's

\footnotetext{
32I. Lodhi, supra note 308, ๆ 26.

322. Id. \44.

323. Lodhi, supra note 300, \ 207.

324. Lodhi, supra note 308, ๆ 44.

325. Id. ๆ 45 .

326. Id. ๆ II.

327. Id. ๆ 20.
} 
mind." The court sentenced Lodhi to Io years imprisonment for the possession and collection of the materials related to terrorism and 20 years for doing an act in preparation for a commission of a terrorist act, to be served concurrently. This decision was upheld by the Court of Appeal. ${ }^{328}$

Is the court's decision justifiable and fair? If the fault requirement, as the court ruled, should be limited only to the awareness of the act of preparation or facilitation, without a need to prove that an accused intended to facilitate or finance either a specific or general terrorist act, any preparatory act that is presumed to be connected to some sort of unplanned and unforeseen terrorist acts should be punished. This is a "significant extension of concepts of criminal liability" 329 as it imposes liability and heavy punishment on a person with unclear criminal intent, who proceeds with the collection or possession of materials—such as obtaining a map, asking for the price of chemicals, or possessing a document about how to make explosives - that might never be used for any terrorist act. There was no proof that a terrorist act was even planned. Although the traditional criminal law has long identified offenses based on complicity in a crime or attempt to commit a crime, the application of this fault requirement colors otherwise innocent conduct as a serious offense at a very early stage.

This mental element also cannot even be justified from a purely subjectivist approach, which imposes liability on the basis of a person's intention or the knowledge with which the person acted, regardless of whether the commission of the offense is incomplete or physically impossible. ${ }^{330} \mathrm{~A}$ subjectivist approach to the preparatory offenses such as financing of a terrorist act would require a high standard of the mental element, which would be actual knowledge of the subsequent terrorist offense. But when there is no need to prove knowledge of any terrorist act, "any remaining knowledge of a terrorist activity would have to be extremely tenuous, abstract and hypothetical." 331 So there is a great risk that an awareness of a terrorist act could be nothing more than possessing a jihadi CD or "reckless or angry talk" or expression of "extreme political or religious

328. Lodhi v. Regina (2007) NSWCCA 360 (Austl.).

329. Andrew Lynch \& George Williams, What price security? Taking stock of Australia's anti-terror laws i8 (2006).

330. See Antony Duff, Criminal attempts igi-92 (i996). See also McSherry, supra note 278 , at 153 .

33I. Kent Roach, Terrorism offences and the Charter: A comment on R. v. Khawaja, II(3) Canadian Crim. L. Rev. 27I, 286 (2007). 
views about past or future acts of terrorism or about known terrorists."332 Such a fault requirement, of course, would not be supportable by a subjectivist approach.

In addition, this loose reference to the mental element appears to unfairly reverse the burden of proof: that is, by not being required to link the act of collection or provision to any material terrorist act, the prosecution seems to have to prove little; and then the accused bears an evidential burden of exculpation, by introducing evidence that his conduct had nothing to do with commission or preparation of a terrorist act. Although the prosecution needs to refute the accused's claim beyond a reasonable doubt, the accused must first put them to the task of doing so by first establishing an evidential case that his actions were innocent. ${ }^{333}$

The shifting of the evidential burden is also of concern because of the breadth with which the fault element is identified by the Lodhi court. There is no doubt that by not being required to prove the intention of the accused as to the subsequent crime, the prosecution can precipitately lay charges on those who are strategically preparing for the commission of an offense; but it does not "provide others with sufficient certainty about what could expose them to prosecution." 334 So an innocent person who, for example, provides funds in response to the request of an unknown impoverished student, who later turns out to be a suicide bomber, ${ }^{335}$ can put herself at risk of being charged and convicted for financing terrorism if the person cannot prove that she did not intend or know the funds would be used for the commission a terrorist act.

Despite these criticisms, the presumption of innocence seems to be becoming so insignificant (at least in a democratic country such as Australia) to policymakers, legislators, and courts that they do not even consider it necessary to give a reason for imposing a burden on the accused. The neglect of the presumption is well reflected in the reasoning of the Australian Minister for Justice and Customs when he justified terrorism offenses as follows:

332. Id.

333. Lynch \& Williams, supra note 329, at 20.

334. Id. at 2O-2I.

335. Princess Haifa of Saudi Arabia, wife of the ambassador to Washington provided funds in response to request of an unknown student who was actually a suicide bomber. See Abdel Bari Atwan, The secret history of al Qaeda i2i (rev. ed., 2008). 
In the security environment that we are dealing with, you may well have a situation where a number of people are doing things but you do not yet have the information which would lead you to identify a particular act... When you are dealing with security, you have to keep an eye on prevention of the act itself as well as bringing those who are guilty of the act to justice... [T] he original intention of the legislation [is] to remove any doubt that a person can be prosecuted for a terrorist act and acts preparatory to a terrorist act, and that our agencies can investigate such acts even if a specific target has not been identified. ${ }^{336}$

4. Is general knowledge of a terrorist act sufficient? Knowledge v. intention: $R$ v. Khawaja

In introducing a mental element for terrorism offenses that are by nature preparatory and do not need to be connected a specific terrorist act, a Canadian court held that a general knowledge of a terrorist act is sufficient. Khawaja was charged, among other charges, with developing, working on, and possessing an explosive substance with the intent to perform a terrorist act-namely, in what became known as the British fertilizer bomb plot. Unlike the trial court, which dismissed these charges because the prosecution could not prove that the accused knew he was assisting in the fertilizer bomb plot, to secure the conviction, ${ }^{337}$ the Ontario Superior Court of Justice relied on Section 83.19(2) of the Canadian Criminal Code, which states that "a terrorist activity is facilitated whether or not the facilitator knows that a particular terrorist activity is facilitated; or any particular terrorist activity was foreseen or planned at the time it was facilitated."338

The accused argued that the qualifiers in this provision are not consistent with the approach of the traditional criminal law as it does not require adequate levels of subjective fault, which would be knowledge or intention related to a specific terrorist act (in this case, the British fertilizer bomb plot). ${ }^{339}$ A concern was also raised as to how a person can knowingly facilitate a terrorist act when he does not know that "any particular terrorist activity was foreseen or planned at the time it was

336. Senator Chris Ellison, reprinted in LyNCH \& Williams, supra note 329, at 19.

337. The decision of the trial court is cited in R v. Khawaja (2010) ONCA 862, I03 O.R. (3d), 9253.

338. R v. Khawaja (2008) O.J. No. 4244; 2008 ON.C.

339. R v. Khawaja (2006) 42 C.R. (6th) 348 , I 3 I. 
facilitated." 340 There seems "to be little or no mens rea at the time the actus reus of facilitation was committed." 341

The Ontario Superior Court, however, accepted the prosecution's argument that these qualifiers seem designed to address cases in which a terrorist cell may not know the specific nature of the terrorist act until the last moment. ${ }^{342}$ But, unlike the Australian court's ruling, the Ontario Superior Court added an extra requirement by concluding that "it is unnecessary that an accused be shown to have knowledge of the specific nature of terrorist activity he intends to aid, support, enhance or facilitate, as long as he knows it is terrorist activity in a general way." 343

The Ontario court's fault requirement of general knowledge of a terrorist act is different from the Australian court's fault requirement, in which the prosecution is not required to prove that the accused knew or intended to support either a specific or general terrorist act, meaning that the accused does not need to know that any terrorist act is planned or foreseen at the time it was facilitated or financed. According to the Canadian court's ruling, the accused may not know the specific details of the subsequent terrorist act but does need to know "an act of terrorism is coming." 344 This reading of the fault requirement is similar to the reading upheld by some other jurisdictions. For example, in Sweden, "there is a need to show that funds were provided with intent that a particular serious crime sooner or later will be carried out."345

340. Id. 9 34. See also Kent Roach, The New Terrorism Offences in Canadian Criminal Law, in Terrorism, Law, and Democracy: How is Canada changing following Septembr ir?, II7-20 (David Daubney et al., ed. 2002).

34I. Id.

342. Khawaja, supra note 338 , 979 . Rutherford J. referred to a transcript of a videotape of Bin Laden, who said: "Brothers, who conducted the operation, all they knew was that they have a martyrdom operation and was asked each of them to go to America but they did not know anything about the operation, not even one letter. But they were trained and we did not reveal the operation to them until they are there and just before they boarded the planes ... those who were trained to fly did not know the others. One group of people did not know the other group." Khawaja, supra note 339, ๆ 3 I.

343. Khawaja, supra note 339, 9 30. This decision was upheld by the Supreme Court of Canada. See R v. Khawaja (2012) 3 S.C.R. 555, ๆ $60-61$.

344. Roach, supra note 33I, at 286.

345. FATF, The third mutual evaluation/detailed assessement report: Anti-money laundering and combating the the fianncing of terrorism: Sweden, II34 (Feb. I7, 2006). 
Although it seems that the Canadian court's extra fault requirement satisfies minimum standards of knowledge, since it requires some type of material or actual connection between the act of preparation and facilitation and the subsequent crime, there are three sources of uncertainty regarding the breadth of such a fault requirement. First, although this fault requirement is broad enough to secure the conviction of those who facilitate the commission of a terrorist act without knowing the specific details of that terrorist act until the last moment, it imputes guilt to those who are remotely and indirectly linked to a terrorist act, and who do not have any intention to finance or facilitate any terrorist act, or do not know how their conduct will serve terrorism. For example, a restaurant owner who knows that certain customers are using his restaurant to plan a terrorist act can be held criminally liable for financing a terrorist act, the same as those who are directly involved in the facilitation of that terrorist act. ${ }^{346}$ The court may not accept the accused's argument that he did not have any particular intention to finance the terrorist act, and that his main purpose was to gain money for his business. The court may argue that whatever his purpose was, he knowingly made his restaurant available to be used for planning a terrorist act. ${ }^{347}$

In addition, it appears that this mental requirement suggests a mens rea element closer to recklessness or negligence than a knowledge requirement. That is, if an accused does need to have knowledge of the specific nature of an upcoming terrorist act, he cannot be absolutely or virtually certain that his funds or donation will be used for the commission of the terrorist act. It seems that the Judge in Khawaja case admitted such an interpretation by concluding that "I see nothing wrong in asking, indeed expecting law-abiding citizens to avoid any knowing activity that aids, supports or advances terrorist activity or a group engaged in such activity." 348 However, his conclusion was criticized as it "runs the risk of blurring the distinction between punishing a person as a terrorist for their subjective fault or for their negligence in not taking reasonable steps to avoid assisting terrorists." ${ }^{349}$ It was pointed out that any understanding that negligent engagement in the facilitation or financing of a terrorist act would suffice

346. Kevin E. Davis, Cutting off the flow of funds to terrorists: Whose funds? Which funds? Who decides?, in The security of Freedom: Essays on Canada's anti-Terrorism bill 305 (Ronald J. Daniels, Patrick Macklem, \& Kent Roach eds., 200I).

347. Id.

348. Rutherford J., see Khawaja, supra note 338 , ๆ 36.

349. Roach, supra note 33I, at 286. 
for the offense is inconsistent with the Canadian law [as well as with the Terrorist Financing Convention], which excludes references to negligence and recklessness. ${ }^{350}$ Concern is also raised that it would be unjust to expose both "negligent and intentional assisters of terrorism to the same liability and punishment." 351

Finally, the breadth of the mental element is also worrying as it may impose liability on innocent conduct not carried out for the commission of any terrorist act unless otherwise proven. For instance, if a member of a terrorist group, which is planning a terrorist act, engages in fund-raising for religious purposes, he can be charged for terrorist financing if he knows of this possibility, even if it is only remote, as all elements of the offense exist. The act of fund-raising along with the knowledge of an upcoming terrorist act provides sufficient grounds for the prosecution to seek conviction for terrorist financing without a need to prove that he intended to finance the terrorist act. The accused can be held liable for the financing of a terrorist act if he fails to prove-in the sense of providing some evidence to disturb the inference of his knowledge-that the act of fund-raising was carried out for different purposes, and that he did not think it was to be used for terrorism. The imposition of such liability on a person only on the basis of mere knowledge about an upcoming act is unjustifiable. This brings full circle the argument for the necessity of proving the actual knowledge of the terrorist destination of funds, or the intention that the funds will be used for the commission of the subsequent offense. However, proving such intent limits the scope of terrorist financing to an inchoate offense or complicity in the crime of terrorism itself. This was the interpretation that the supporters of the Convention always intended to avoid.

\section{B. Financing a Terrorist Organization}

Despite the fact that the Convention failed to define "terrorist" or "terrorist organization," cutting off financial resources of terrorist organizations is another and later much-used method of addressing terrorism financing. However, applying the Convention to suppress the financing of terrorist organizations raises questions about what amounts to the fault elements of the offense of the financing of terrorist organizations.

350. Id.

35I. Id. at 286. 
This mainly results from the ambiguity of the provisions of the Convention. The term "funds" has, as illustrated above, a broad meaning that includes any materials, legal or illegal tools, fungible and non-fungible resources, that may not even be usable for the commission of a terrorist act, and that in themselves may not indicate a disposition to support terrorism. Also, according to Article 2(3) of the Convention, the terrorist end-use of funds is irrelevant, which means there is no need to prove the link between financing and a terrorist act. Therefore, in the case of financing a terrorist organization, it is not clear what the elements of intention-that funds should be used to carry out a terrorist act, or the knowledge that funds are to be so used-refer to. What can be inferred from the wording of the Convention is that the Convention should not be read to mean that mental states of financers has to refer to any terrorist offenses being prepared or carried out by a group, otherwise the offense of financing terrorist groups would come close to the concept of complicity in the sense that it depends on the commission or preparation of a specific subsequent terrorist offense. For a similar reason, the proof of the knowledge of the intention of the recipient of funds to commit specific offenses is not intended to be the fault element.

Such a vague reference to a connection between a financer's activities and the illegal activities of a group has been the cause of some confusion. Is it enough if a financer knows the identity of the recipient of funds as a designated terrorist group or a group involved in terrorist activities? What if the financer knows the recipient is a terrorist group, but intends to further the lawful purposes of the group? Does the offense need specific intent? Or is does it only require recklessness? These questions will be examined in this section. In order to avoid over-complication of this discussion, it is assumed that the law of a State is clear on the definition and scope of "terrorist organization." The discussion also does not address whether and how the political process of designating a group as terrorist may impact the criminalization of terrorist financing.

\section{Does knowledge of the identity of the recipient of funds suffice?}

The most direct way to hamper a corrupt and dangerous group is to proscribe it outright, including by making the knowing provision of any support to the group an offense. But there are multiple legal challenges targeting such a fault requirement. First of all, if the knowledge of the identity of the recipient alone suffices for intent, somewhat similar to status or situational 
offenses, the offense of financing terrorist groups seems to impose punishment on an act based only on the connection of that act with others' state of being, not to their criminal conduct. In other words, the physical element of collecting or providing funds is innocuous enough; it is (the knowledge of) the status of the person or the group with whom people associate that criminalizes these acts. Consequently, the intent of financers is irrelevant.

Whereas the principle of legality seeks to punish criminal conduct or participation in a criminal act and not the status of offenders, ${ }^{352}$ and whereas the principle of mens rea emphasizes that people "should be held liable only for events or consequences which they intended or knowingly risked," 353 one may argue that applying a status-based approach to terrorist group-related offenses is "neither novel, nor extraordinary." ${ }^{354}$ The criminal law has long included "status offences," such as consorting with criminals, that penalize people "on the basis of whom they know and associate with." 355 However, these offenses have usually been considered to be of a less serious nature (summary offenses), and a result of the controversial expansion of police powers in response to the threat of criminal groups and gangs. ${ }^{356}$ In contrast, terrorist organization and association offenses are classified as serious offenses that carry hefty sentences ${ }^{357}$ and inflict grave damage to the accused's reputation.

Historically, it was also unprecedented in democratic States to apply such an approach to the mens rea of criminal organization and association offenses. For example, in dealing with cases of membership in and

352. McSherry, supra note 278 , at 157 .

353. AshworTh, supra note 280 , at 75 .

354. Simon Bronitt, Director, National Europe Centre, Australian National University, Australia's legal response to terrorism: Neither novel nor extraordinary?, Address at The Year in Review Conference, Castan Center for Human Rights Law, Melbourn, Australia (Dec. 4, 2003), cited by McSherry, supra note 278, at 157.

355. Jude McCulloch \& Sharon Pickering, Pre-crime and counter-terrorism: Imagining future crime in the 'war on terror', 49(5) BRIT. J. Criminology 268, 633 (2009).

356. Alex Steel, Consorting in New South Wales: Substantive offence or police power? 26(3) U.N.S. WALES L. Rev. 567, 576 (2003), cited by McSherry, supra note 278, at I58. It should be noted that in the so-called "war on terror," there are some serious status offenses with heavy sentences. For example in Australia, the offense of "being "knowingly concerned" in the importation of illicit drugs" carries the maximum penalty of life imprisonment. However, these offenses are not common. See Simon Bronitt \& Bernadette McSherry, Principles of CRIMINAL LAW I62 (200I).

357. McCulloch \& Pickering, supra note 355, at 633. 
association with quasi-political groups seeking the violent overthrow of the government as well as social welfare goals, such as the Communist Party, U.S. courts have ruled that

[i]n our jurisprudence guilt is personal, and when imposition of punishment on a status or on conduct can only be justified by reference to the relationship of that status or conduct to other concededly criminal activity (here advocacy of violent overthrow), that relationship must be sufficiently substantial to satisfy the concept of personal guilt. ${ }^{358}$

However, where the relationship between the accused's involvement and the criminal activities of a group is "too tenuous to permit its use as the basis of criminal liability," 359 or where the involvement includes a status or conduct that establishes a relationship with a criminal enterprise rather than its criminal activities, the principle of personal guilt may be satisfied if the prosecution proves that the accused "knew the organization engages in criminal activity, and that was his purpose to further that criminal activity." 360 This approach was later applied to civil cases in which, for example, the Supreme Court ruled that:

Civil liability may not be imposed merely because an individual belonged to a group, some members of which committed acts of violence. For a liability to be imposed by reason of association alone, it is necessary to establish that the group itself possessed unlawful goals and that the individual held a specific intent to further illegal aims. ${ }^{361}$

Even with regard to providing fungible resources, the U.S. Supreme Court, in another case, ruled that the mere provision of money (membership dues) to the organization did not establish a "meaningful association with the party" on the basis of which the accused could be liable. ${ }^{362}$ The court adopted the position of prior courts by requiring the prosecution to prove that the accused was aware of the nature of the organization and its involvement in illegal activities, and he intended to contribute to those criminal activities by paying dues and attending some meetings. ${ }^{363}$

\footnotetext{
358. Scales v. United States (I96I), 367 U.S. 203, 205, ๆ $224-25$.

359. Id. $₫ 226$.

36o. Id. ๆ 226.

36r. NAACP v. Claiborne Hardware Co. (1982), 458 U.S. 886, ๆ 920.

362. Gastelum-Quinones v. Kennedy (1963), 374 U.S. 469, ๆ $976-77$.

363. Id. ๆ $477-8 \mathrm{o}$.
} 
Similar to the above-mentioned practice, ${ }^{364}$ the Palermo Convention, in establishing criminal group and association offenses, introduces a specific

364. In the United States, there was a controversy on whether such a fault requirement can be applied to terrorist financing. Whereas in the early cases of terrorist financing, courts applied the fault requirement by holding that a donor is not liable for supporting a designated terrorist group so long as he does not know or specifically intend that the recipient of funds would use the support to further the terrorists functions of that group (see, e.g., United States v. Al-Arian (2004), 329 F. Supp. 2d, I294), in subsequent cases, courts took the position that the Communist Party court's decisions are not applicable to terrorist financing. It was argued that the Communist Party cases "address[ed] situations where people are punished by reason of association alone... in other words, merely for membership in a group or for espousing its view." Instead, the terrorist financing offense criminalizes "the act of giving material support, and there is no constitutional right to facilitate terrorism by giving terrorists the weapons and explosives with which to carry out their grisly missions. Nor, of course, is there a right to provide resources with which terrorists can buy weapons and explosives" (see Humanitarian Law Project v. Reno (2000), 205 F.3d II30, $9 \mathrm{II} 33$ ). It is also argued that terrorist groups are so tainted by their criminal conduct that any contribution to such groups aids their unlawful purposes by freeing up resources that can be used for terrorism. So, because all contributions can be directly or indirectly used for terrorism, it does not matter how a financer intends his contribution to be used. As long as he knows the group that he is supporting is a terrorist group, he is criminally liable (id. $9 \mathrm{I} \mathrm{z} 6$ ).

As Jonakait argues, this "action-membership distinction" reasoning is not persuasive for following reasons. Although membership seems to be a status, a membership is not acquired "passively"; "Except for memberships resulting from birth, it takes some sort of act to become a member of a group" (see Randolph N. Jonakait, The mens rea for the crime of providing material resources to a foreign terrorist organization, 56 BAYLOR L. REV. 86I, 905 (2004)). Also, other courts applied the same mens rea requirement to the cases in which "the defendant had engaged in variety of activities [beyond mere membership] to support the Communist Party including organizing new members, teaching Communist principles to students and members, and soliciting contribution for the Communist party" (see Humanitarian Law Project v. United States (2003), 352 F.3d 382, ๆ 395 ).

In addition, membership is a way of providing human resources to an organization. If any contribution to a terrorist group frees up resources that can be used for terrorist acts, one active member may very well free up another member to undertake illegal actions in furtherance of the group's illegal purposes (id. \9I0).

Moreover, the courts in Communist Party cases applied this fault requirement (the specific fault requirement) to include not only membership, but also "association." Association, from these courts' perspective, has a broader meaning than "membership" (see, e.g., NAACP v. Claiborne Hardware Co., supra note 361, 9 886). It captures the concept of financing; i.e., "One can associate with a group in more ways than joining its formal membership rolls"; people may "associate with a group by donation their money, services or goods" (Jonakait, supra, at 90I). Also, in terms of the right of association, it is argued that "the distinction between association and material support is illusory. Groups cannot exist without the material support of their members and associates. If the right of association 
mental element far greater than the knowledge of the identity of a criminal group. According to Article 5(I)(a) of the Convention, the offense of "active" participation in the criminal activities of a criminal organization requires knowledge of either the aim and general criminal activity of the group or its intention to commit the crimes addressed by the Convention. With regard to the involvement in noncriminal and supportive activities of a criminal group - activities which "may not constitute crimes, but they perform a supportive function for the group's criminal activities and goals" 365 - the Convention introduces an additional requirement: "knowledge that such involvement will contribute to the achievement of a criminal aim of the group." 366 Such an approach can be seen in the implementation of the Convention at the national level. For example, in Canada, a person who "knowingly... participates in or contributes to any activity of [a] criminal organized organization" is criminally liable if such involvement or contribution is made with "the purpose of enhancing the ability of [the] criminal organization to facilitate or commit an indictable offence."367

Practically, this knowledge requirement-convicting a person for the provision of funds to a group on the grounds that he or she knows the group is designated as criminal or it is involved in criminal activitiescauses some concern in terms of including both guilty and non-guilty mental states. A U.S. court tested several hypothetical situations against this knowledge requirement:

Under [the construction of this knowledge requirement], a cab driver could be guilty for giving a ride to a [terrorist organization] member to the UN, if he knows that the person is a member of a [terrorist organization] or the member or his organization at sometime conducted an unlawful activity in a foreign country. Similarly, a hotel clerk in New York could be committing a crime by providing lodging to that same [terrorist organization] member under similar circumstances as the cab driver. ${ }^{368}$

meant only that one had the right to join organization but not to support them, the right would be empty." (See David Cole, The new McCarthyism: Repeating hisotry in the war on terrorism, 38 HaRV. C.R.-C.L. L. ReV. I5 (2003)).

365. See also United Nations Office on Drugs and Crimes "Legislative guides for the implementation of the United Nations Convention against Transnational Organized Crime and the protocol thereto" 2004, at 24.

366. Palermo Convention, Art. 5(a)(ii)(b).

367. Canadian Criminal Code, Art. 467.II.

368. United States v. Al-Arian (2004), 308 F. Supp. 2d I322, ๆ I I337-38. 
The court concluded that this knowledge element does not satisfy the requirement of personal guilt because the knowledge of the identity of the recipient or the knowledge of the unlawful activities of a group is not strong enough to impute guilt on the donor's conduct; that is, "when criminality and punishment are justified by a relationship to others' conduct, that relationship must be sufficiently substantial to constitutionally support criminal liability." 369

To support this conclusion, the court discussed another hypothetical situation:

\begin{abstract}
$\mathrm{A}$ and $\mathrm{B}$ are members of a [foreign terrorist group or an] FTO. The FTO exists to oppose and remove (by violent and non-violent means) a foreign government. A opposes the FTO's use of violent means to accomplish its goals. B has no problem with the group's use of violence and wants to raise funds for weapons to further that interest. B travels to where A lives to raise money. A does not know that $B$ is coming to fundraise on behalf of the FTO. A picks B up at the airport. A allows B to stay in his home, use his telephone, and use his house to entertain other FTO members while $\mathrm{A}$ is at work. B fundraises while A is gone. Under the government's construction of Section $\left.2339 \mathrm{~B}(\mathrm{a})(\mathrm{I}),{ }^{370}\right]$ A is criminally liable for providing transportation, lodging, communications equipment, and facilities, and, if the money raised results in the death of any person, he will face life in prison. A's criminal liability is inextricably connected to his association with B and the FTO. Further, the level of A's criminal punishment is totally dependent on B's and other members of the FTO's criminal conduct. ${ }^{371}$
\end{abstract}

Concern also arises that such a knowledge requirement imposes liability on well-intentioned financers. That is, because a financer does not need to intend that his or her funds be used for terrorist activities or for the terrorist functions of a group, no humanitarian support can be sent to any

369. Al-Arian, supra note 364, $9 \mathrm{I} 300$.

370. Section $2339 \mathrm{~B}(\mathrm{a})(\mathrm{I})$ of the U.S. Criminal Code states, "Whoever knowingly provides material support or resources to a foreign terrorist organization, or attempts or conspires to do so, shall be fined under this title or imprisoned not more than 15 years, or both, and, if the death of any person results, shall be imprisoned for any term of years or for life. To violate this paragraph, a person must have knowledge that the organization is a designated terrorist organization..., that the organization has engaged or engages in terrorist activity ..., or that the organization has engaged or engages in terrorism."

37. Al-Arian, supra note 364, 9 I300. 
designated terrorist group. ${ }^{372}$ This has a chilling effect on those who seek to provide material resources to "the non-violent humanitarian and political activities" of designated groups. ${ }^{373}$ It also has a tragic effect on the provision of humanitarian aid to the disaster and war zone controlled by designated terrorist groups. ${ }^{374}$ In addition, this seems to be in contrast to the intent of the drafters of the Terrorist Financing Convention, who desired to criminalize only financing cases carried out "unlawfully." As mentioned earlier, the qualifier "unlawfully" was included in the definition of "offense" to add "an element of flexibility by, for example, excluding from the ambit of application of the draft Convention legitimate activities, such as those of humanitarian organizations and ransom payments." 375

\section{Is the knowledge requirement the only solution?}

Despite all of the above-mentioned critiques, this knowledge requirement is justified by the dangerous and extraordinary nature of terrorist groups. An often-used line of reasoning argues that terrorist organizations are

so tainted by their criminal conduct that any contribution to such an organization facilitates that conduct.... It follows that all material support given to such organizations aids their unlawful goals.... [T]errorist organizations do not maintain open books. Therefore, when someone makes a donation to them, there is no way to tell how the donation is used .... [E]ven contributions earmarked for peaceful purposes can be used to give aid to the families of those killed while carrying out terrorist acts, thus making the decision to engage in terrorism more attractive. More fundamentally, money is fungible; giving support intended to aid an organization's peaceful activities frees up resources that can be used for terrorist acts. ${ }^{376}$

Therefore, since any contribution to a terrorist group can be directly or indirectly utilized by a group for the promotion of the group's illegal

372. David Henrik Pendle, Charity of the heart and sword: The material support offense and personal guilt, 30(3) Seattle U. L. Rev. 777, 785 (2007).

373. Humanitarian Law Project v. United States (2003), supra note 362, ๆ 385.

374. Halimuddin Sandi, U.S. counterterrorism laws block international humanitarian aid, World Policy Blog (Dec. 19, 20I3, 3:00 PM), http://www.worldpolicy.org/blog/20I3/12/ I9/us-counterterrorism-laws-block-international-humanitarian-aid.

375. U.N. Doc. A/C.6/54/L.2, supra note Io, Informal summary of the discussions in the Working Group, prepared by the Chairman, 967 .

376. Humanitarian Law Project v. Reno, supra note 364, 9 1136. 
purposes, the financer's intention does not matter; that is, "Once the support is given, the donor has no control over how it is used." 377

Although this reasoning may have some merit, it can be criticized for seeking the conviction of a donor on the basis of how a terrorist group could use the donation, not on the basis of the mental state of the donor. ${ }^{378}$ This approach is in contrast to the approach used to address groups such as the Communist Party in the United States or the approach adopted to criminalizing the offenses of organized criminal groups in which the focus is "on the activities and mental states of the associating individual [and] not on how an organization ... might further its illegalities from an act of association."379

In addition, the premise that terrorist groups could use any donation for terrorist purposes does not really justify why there is no need to introduce a specific intent greater than the knowledge of the identity of the group; on the contrary, to satisfy the principle of personal guilt, such reasoning necessitates a higher intent requirement. In fact, if the focus of the criminalization of terrorist group offenses is on donation and how a group might use the donation, the evidence should be sufficiently strong in demonstrating that the donation is substantial enough in its value or its effects to strengthen the group's illegal activities. Consequently, to impute guilt on the donor, it should be proved that the donor knew (had a specific intent) that his substantial donation would contribute to the achievement of the criminal aims of the group.

However, the imposition of a specific intent requirement is opposed for (among other reasons discussed later) creating a dangerous loophole for terrorist organizations and their supporters to raise and receive funds and avoid prosecution. Although specific intent can be inferred from the nature of support when the financing is involved in or related to the provision of weapons or explosives to a terrorist group, ${ }^{380}$ this may often not be the case

377. Id. $9 \mathrm{II} 34$.

378. Jonakait, supra note 364 , at 909.

379. Id.

380. See U.S. v. Aref (2008), 553 F.3d 72. In this case, the court found the defendants guilty of multiple counts arising out of money laundering conspiracy intended to support a sting operation of the secret importation of a missile for a terrorist group. Although the court argued that the prosecution need not prove the specific intent of the defendants. To uphold the conviction, the court focused on the fact that the defendants knew from the nature of their support that they were contributing to the illegal aims of the group. 
when the support contains "dual use" and fungible resources. To illustrate the "security flaws" of this requirement, the following hypothetical situation is often discussed:

[I]f a person writes a check to [a terrorist group involved in both violence and humanitarian activities] for \$10,000 and writes on the "memo" line of the check "for educational purposes only," the donor would not be liable under the specific intent standard so long as there was not other evidence showing an intention to aid terrorism. But, whether the donor intended to aid terrorism or not, the check could be used for many other projects, including illicit ones. ${ }^{381}$

Moreover, no criminal liability could be imposed on a donor who is told (deceived) by the fundraiser working on behalf of the group that the money would be spent "for the support of orphans," not on any violent act. Under the specific intent requirement, the intentional, deceived, and reckless donors should be acquitted when the prosecution cannot prove the specific intention of the donors. So the donation can flow into the hands of terrorists. ${ }^{382}$

\section{Reckless financing of a terrorist group}

To close this loophole and to avoid legal challenges resulting from the imposition of only the knowledge requirement, some suggest a lower mental element of recklessness as an alternative mens rea to the specific intent. ${ }^{383}$ Under the recklessness requirement, ${ }^{384}$ a person should be held

38r. Pendle, supra note 372, at 804.

382. Robert M. Chesney, The sleeper scenario: Terrorism-support laws and the demands of prevention, 42(I) HARV. J. ON LEGIS. 70-7I (2005).

383. LeHTO, supra note 99.

384. The recklessness requirement at issue is different from "reckless knowledge," which is an alternative mens rea to the knowledge requirement. In the case of financing terrorist groups, "reckless knowledge" refers to the circumstances where the financer disregards the risk that the group that he is supporting is a designated group, or engages, or has engaged in terrorist activities, or is a front for a terrorist group. The risk also includes cases where a fund raiser is a front for a terrorist group. Under this requirement, it does not really matter what intent prompts financing; nor does it need to prove that the financer was reckless about the terrorist's end-use of the funds. Instead, it is sufficient for the prosecution to show that the financer was aware of a substantial risk that the group is a proscribed group or engages in terrorist activities "and that such a risk was unjustifiable." (See R v. Vinayagamoorthy (20I0), VSC I48, ๆ 6.) Due to its broadness, the implementation of such a requirement would cause greater due process concerns than those resulted from the implementation of the knowledge requirement mentioned here. Regardless, this intent element is applied 
to be reckless about the terrorist end-use of funds when the person knows that the group that he is financing is a designated terrorist group, or engages in terrorist activities, but he proceeds with financing the group despite knowing the risk that the supplied resources will be used to further the illegal aims of the group. ${ }^{385}$

It is argued that the structure of the terrorist financing offense defined by the Convention gives support to such a mental requirement. ${ }^{386}$ The Convention does not require that the mental elements of knowledge that funds collected or provided are to be used for the commission of a terrorist act, or of intention that the funds will be used for terrorism, be proven in relation to any actual terrorist act. Also, the funds need not be "actually" used for the commission of any terrorist act, so they do not necessarily have to have a substantial effect on the commission of a terrorist act. In the case of financing terrorist groups, such a structure is claimed to inject a concept of foreseeability into the mental elements of the offense; that is, when a financer intends a terrorist end-use of his funds, it is not the financer but the recipient of the funds "whose actions may bring about the intended result at a later, unspecified point of time." 387 The financer also does not have control over the decision of the recipient; nor can there be "absolute certainty" that the funds will be used for such purposes, ${ }^{388}$ especially if the funds are in a fungible form, and the recipient (group) is involved in multiple activities of a humanitarian as well as violent nature. Similarly, with regard to the knowledge element, the financer is far "too removed from" terrorist acts that the recipient may carry out "in terms of time and knowledge." 389 Also, the practical effect of the supplied funds on those acts is neither foreseeable nor easy to determine. Therefore, when it is stated that the financer knows that the funds are to be used for terrorism, it means he either actively takes the risk that the funds will be used by the recipient for terrorism, or foresees, but ignores, "the possibility, sometimes even the

(although rarely) in some jurisdictions. For example, under Section I02.6 of the Austrian Criminal Code, a person will be sentenced to is years imprisonment for receiving funds from, or making funds available to, an organization if "the person is reckless as to whether the organisation is a terrorist organisation."

385. Pendle, supra note 372, at 805.

386. Lehto, supra note 99, at 29I.

387. Id. at 283 .

388. Lavalle, supra note 169 , at 499.

389. LeHTO, supra note 99, at 292. 
probability that the funds may be used for the commission of terrorist acts." ${ }^{390}$ In the both cases, the financer takes the risk that the funds will be used by others for terrorism. Whereas in the former, the risk is willingly taken, in the latter, the risk seems to be ignored, meaning that the risk is deliberately taken in the hope that it does not cause harm.

In practice, it is believed that this mental requirement would secure the conviction of those who know or foresee who and what their supplied funds will support, but they disguise their intention or foolish faith through, for example, a statement in the memo of a check. ${ }^{391}$ Unlike the knowledge requirement in which the donor can be convicted for merely knowing that the group is a terrorist group (regardless of his intention), the recklessness requirement would permit "non-reckless" resources to aid the humanitarian goals of a group, resources such as sending medicines and non-controversial materials to areas having suffered from natural disasters and controlled by terrorist groups. ${ }^{392}$

However, there are some doubts about whether a recklessness requirement would be a convincing and viable alternative as a mental element for the offense. From the Convention's point of view, it should be noted that, although the structure of the offense defined by the Convention implies that the offense may include cases of less certain mens rea, any interpretation whereby the mens rea of the offense is defined in terms of recklessness or negligence is inconsistent with the actual wording of the Convention, which clearly requires only two mental elements, intention and knowledge. In addition, such an interpretation contradicts the aims of the Convention's drafters. During the negotiation on the Convention, all of the proposals aimed at imposing liability on those who collect or provide funds in circumstances "where there is a reasonable likelihood that they will be used for terrorist purposes" were rejected. ${ }^{393}$ In addition, the drafters of the Convention added the qualifier "wilfully" to the definition of the offense,

390. Id. at 293.

39I. Chesney, supra note 382, at 70-7I.

392. Id.

393. U.N. Doc. A/AC.252/1999/WP.20, reproduced in U.N. Doc. A/54/37, supra note 9, at 20. Similar proposal was put forward to criminalize "the financing of a person or organization in the knowledge that such financing is or is likely to be used, in full or in part, in order to prepare or commit" a terrorist act. See U.N. Doc. A/AC.252/1999/WP.I6, reproduced in U.N. Doc. A/54/37, id., at 33 . 
"to emphasize that the financing had to be done deliberately, not accidently or negligently." 394

In practice, although using a recklessness requirement would secure the conviction of those who "convincingly plead ignorance while secretly desiring" the terrorist end-use of their funds, ${ }^{395}$ the examination of some of the hypothetical cases used above illustrates that this recklessness requirement would not be able to alleviate the due process concerns of sweeping breadth and vagueness. In terms of overbreadth, the offense under this recklessness requirement would still include non-guilty mental states in the scope of criminality. The first example is the hypothetical case in which A, a member of a terrorist group who opposes the group's use of violence, allows $\mathrm{B}$, another member of the group who supports the group's use of violence, to use his house, phone, and car, in order to do B a favor. Without informing A, B uses A's property to raise funds for the group. Under the recklessness requirement, $A$ would be still be liable for letting a terrorist friend use his property if $\mathrm{A}$ foresees the possibility that $\mathrm{B}$ may use his property for raising funds, and if B may give the funds to the group, and if the group may use the funds for terrorist purposes. Raising funds is not wrongful or harmful. Also, there is nothing wrong with giving the money to the group. The possibility that the funds may be spent by the group (if $\mathrm{B}$ gives the funds to the group) for terrorist purposes should not be risked. But is it really what the concept of recklessness implies? According to the same common law jurisdictions, a person is reckless if the person "foresees that a certain consequence could well follow from his action, not just a remote risk." 396 Such a definition requires the existence of some form of actual risk and its foreseeability by the accused. It seems, at least to me, to be hard to argue that the risk in this hypothetical case - that the funds will be used for the commission or preparation of a terrorist act-meets these requirements as there is no terrorist act committed, attempted, or even planned.

Similarly, in the example of the cab driver who knowingly gives a ride to a member of terrorist group, it is still likely that the cab driver would incur liability for knowingly providing services to a terrorist who is carrying a weapon in his bag, if the driver is aware of a possibility that the suspect terrorist may have a gun. But such a possibility seems so vague that it would

394. Aust, supra note 20, at 295.

395. Pendle, supra note 372 , at 804 .

396. R v. Tipple, (2005), CA2I7/o5 (N.Z.), ๆ 23. 
not be considered in an offense where recklessness suffices as the mental element. Similarly, a hotel clerk could be prosecuted for being reckless in offering the same person services "under similar circumstances as the cab driver." It is pointed out that under the recklessness requirement, providing any fungible resources such as money to a terrorist group would raise liability; ${ }^{397}$ therefore, no explanation would be accepted for writing a cheque to a terrorist group for educational purposes, as the donor knows the group would be free to use the money as it would see fit, but he takes the risk anyway.

The imposition of guilt on the innocent financers in the above cases is neither surprising nor unexpected; it is because their liability would not be inferred from their "advertent recklessness" about a proscribed consequence, or from their "reckless knowledge" of a specific circumstance, but from their mere association with a member of a group whose dangerous or corrupt nature causes the concern that they may use any support for terrorist purposes. The main reason that this mental requirement acquires a sweeping character is its failure to define the relationship between a financer's conduct and the criminal activities of a group. Normally, when the criminal liability of one person is tied to the criminal activity of another, culpability or guilt is imputed to the former on the basis of his awareness or intention (or recklessness) regarding the criminal conduct of the latter, and on the basis of his awareness of his ability to assist the latter to commit the crime. But it seems that this formulation is not applicable to the offense of terrorist financing. That is, to establish an independent offense, the Convention does not require any of these elements: the act of financing should not result in or be related to any subsequent offense, nor must the supplied funds actually be spent for the commission of a terrorist act. Instead, this recklessness standard adds the new element of "terrorist purposes" to the definition of the offense to fill this gap; that is, the financer needs to intend or be reckless in ignoring the possibility that the supplied funds will be used for terrorist purposes.

But what, then, constitutes "terrorist purposes"? No definition has been provided for this phrase. ${ }^{398}$ Literally, the term "terrorist purpose" seems to include conduct of greater scope that just an act of terrorism. One

397. Chesney, supra note 382 , at 84 .

398. The Convention in its Preamble and Art. 2(5)(3) uses the term "terrorist purpose," but no detention has been provided for this category. 
comment is, "This terrorist purpose supposedly consists of the perpetration or preparation of terrorist acts, or the participation in terrorist acts or terrorist training." 399 It can also include activities related to "the maintenance of terrorist structures" of a group; ${ }^{400}$ or if understood in an even broader sense, it can refer to the political or religious ideology of a group. Therefore, if the funds given to a terrorist or a terrorist group "could be used for broad terrorist purposes including but not limited to the preparation of terrorist offences," 401 prosecution would precipitately and largely lay charges on any donor on the grounds of taking the risk that the funds would be used somewhere and somehow for broad terrorist purposes.

It seems that under this view of "terrorist purposes," terrorist groups are "so tainted by their criminal conduct that any contribution to such an organization facilitates that conduct" or "frees up resources that can be used for" that conduct, ${ }^{402}$ and it follows that almost every donation can be assumed to directly or indirectly result in terrorism unless the financer proves otherwise. Therefore, a grocery store manager, for example, could be prosecuted for selling goods to a member of a terrorist group while he foresaw the risk that the goods would meet the basic needs of the group and eventually assist the group to fulfil its terrorist purposes. The accused might only escape conviction if he proves that he had no reason to believe they would be used for terrorist purposes.

But when the scope of terrorist purposes is not precisely defined, what exactly should a donor prove to avoid falling into the scope of the offense? This requirement seems to place a meaningless and heavy burden on a financer without clarifying what he needs to foresee, and avoid, in order to escape conviction.

\section{A specific intent standard: intention or motive?}

Imposition of criminal liability under a higher mens rea standard, that of specific intent, is also controversial and problematic, irrespective of how

399. Kai Ambos, Our terrorists, your terrorists? The United Nations Security Council urges states to combat "foreign terrorist fighters", but does not define "terrorism," EJIL BLOG (Oct. 2, 20I4), http://www.ejiltalk.org/our-terrorists-your-terrorists-the-united-nations-securitycouncil-urges-states-to-combat-foreign-terrorist-fighters-but-does-not-define-terrorism/.

40o. Lehto, supra note 99, at 297.

40I. Id. at 299.

402. Humanitarian Law Project v. Reno, supra note 364, ๆ II36. 
narrowly or broadly the term "terrorist purposes" is understood. Financing "terrorist purposes" can be read to mean an act or acts that enhance the ability of a terrorist group to facilitate or carry out a terrorist act or acts (as the Canadian criminal law indicates). ${ }^{403}$ Under this reading, to acquire criminal liability, a financer needs to know or specifically intend that the funds given to a group will enhance the ability of the group to commit a terrorist act.

Regardless of any controversy that may arise over what constitutes acts enabling a group to carry out its terrorist activities, such a fault element creates a serious evidentiary burden for law enforcement. That is, the prosecution would need to demonstrate what type of terrorist act or acts a group is involved in, how the funds supplied to the group would or could be used for the preparation or commission of those acts, and whether the financer knew or specifically intended such an end-use of the funds. In practice, the proof of such a connection is believed to be a particularly difficult, if not impossible, especially when support is in a fungible form, and a group is involved in multiple activities of humanitarian as well as violent nature. ${ }^{404}$ The critics of this formulation claim that this prosecutorial hurdle "permits skilful terrorist sympathizers to evade detection and slip through the prosecutorial net." 405 In addition, it seems that the Convention does not support such an intent requirement by not requiring the proof of the terrorist end-use of funds.

"Terrorist purposes," in a broader sense, can also be read to include a group's ultimate aims and purposes of (what the Convention regards as) intimidating a public or coercing a government or an organization to do or abstain from doing. Under this definition, the mental element of the offense would be understood in the sense of having intent to enhance the ability of a group to peruse and fulfil its ultimate purposes of intimidation or coercion. In the absence of commission or preparation of any terrorist

403. Canadian Criminal Code $\S 8$ 83.I8.

404. See, e.g., U.S. v. Arnaout, (2005), 43I F.3d. In this case, the accused was charged in several cases including purchasing and providing clothes, boots, uniforms, blankets, tents, $\mathrm{X}$-ray machine, ambulances, and walkie-talkies to an organization that he knew to be involved in violence and military operations. Despite the substantial intelligence and documentation on the close relationship between the accused and Bin Laden dating from mid-1980s, the court dropped his terrorism charges because the prosecution could not prove that the recipient of the resources was engaged in "a federal crime of terrorism," and that the accused intended the donated material to be used to "promote a federal crime of terrorism" ( $\$ IOOI). 405. Pendle, supra note 372, at 778. 
act from which such intent may be inferred, it would be sufficient for the prosecution to introduce evidence that a financer entertains views and purposes similar to those that the group supported holds. Such a reference to the ultimate purposes of a group implies a state of mind closer to a motive requirement than specific intent.

Regardless of whether motive can constitute an essential element of terrorism offenses, the main concern is whether reliance on evidence of political motive, as circumstantial evidence, in the proof of terrorist financing charges would be justifiable and fair. Even though one may assume it is fair, ${ }^{406}$ it should be noted that there is a considerable difference between a person who intends the resources he supplies to be used for the commission or preparation of terrorist acts and a donor who, for example, admires the Palestinians' resistance and their resort to violence to stop the Israeli government from the expansion of its settlement plan, and who supplies resources to the area controlled by Hamas for humanitarian or educational purposes. But under this motive requirement, a court would need to admit evidence about the donor's political views and beliefs (as an essential element of the offense) and uphold his conviction irrespective of what intent prompted the donation. This evidentiary problem indicates that even the imposition of a motive requirement does not guarantee that the offense would not sweep together both guilty and non-guilty mental states.

\section{CONCLUSION}

On the basis of the theory that terrorism (similar to organized crime and money laundering) could also be hindered by the adoption of

406. Roach, supra note 33I. While Roach disagrees with the idea that the mental element of terrorist offenses should be defined with a vague reference to a "political and religious motive requirement... because of its potentially harmful effects on those who may share political and religious beliefs with terrorists and on its harmful effects on the accused by requiring admission of political and religious motive evidence regardless of the balance between its probative value and prejudice" (id. at 27I), he does not found it unsupportable and unfair to define terrorism offenses with an implicit reference to the intention of intimidating the public or coercing a state or an organization. He argues that in comparison with the political and religious motive requirement, according to which courts need to face "the difficulty of determining and judging the true nature of a person's religious beliefs, or the sincerity of their expression," the intent of intimidation and coercion are "easy to determine and judge" and deserve less constitutional protection (id. at 292-93). 
a comprehensive and global system of mechanisms against its financing, a call for the creation of a new convention on terrorist financing was made. As a result, the Terrorist Financing Convention was adopted, obliging member States to regard the preparatory act of financing as an independent offense of terrorist financing. However, examination of the Convention's criminalization provisions has shown that the definition of the offense is far too vague and, in many respects, inconsistent with the traditional principles of criminal law, summarized as follows:

I. The Convention does not provide a solid platform for a better understanding of terrorism, the financing of which it obliges States to criminalize. Its definition of terrorism does not really take into account the underlying problem, which hampers reaching an international agreement on a convention on terrorism: the distinction between terrorism and other forms of armed conflict. It has failed to define "terrorist group." It has not addressed what constitutes "terrorist purposes" or "terrorist activities," while it refers to them.

2. The Convention provides a broad definition of "funds" that seems to include almost anything under the sun. This definition proves controversial when applied at national levels (for example, in the United States' definition of "funds"). The definition of the term "funds" also varies considerably from one member State to another.

3. The Convention's definition of the objective elements of the offense raises serious issues of clarity and certainty. Acts of financing, according to the Convention, include acts of collection and provision. Controversy has arisen over whether the act of collection is prerequisite to the act of provision, or are these two different, but successive offenses? Different approaches have been adopted by different member States.

4. The offense is heavily reliant on poorly defined and ambiguous fault elements, knowledge and intention. To establish an independent offense, the Convention does not require the act of financing to be linked to any terrorist act. But in the absence of preparation or commission of a terrorist act, the Convention has not clarified what a financer needs to know or intend in order to be criminally liable. The mental elements of the offense have been examined in two circumstances within which acts of financing may take place: financing of a terrorist act and financing of a terrorist group.

With regard to the former, by analyzing the Australian case of Lodhi and the Canadian case of Khawaja, it has been illustrated that when the 
financing is involved in collection or possession of funds for the commission or preparation of a terrorist act, any mental requirements other than actual intention and knowledge of the subsequent offense would significantly expand the concept of criminal responsibility beyond the traditional inchoate offenses; it might impose liability on the innocent, on people who are remotely and indirectly are linked to a terrorist act, or people with an unclear criminal intent. It might also result in an unfair and unjustifiable reversal of the burden of proof. However, a requirement of proof of an actual intention or awareness of the subsequent terrorist act would limit the crime of financing to the equivalent of inchoate offenses, which is not supported by the Convention and the FATF.

With regard to the financing of terrorist groups, different alternative fault elements have been tested. It has been illustrated that mere knowledge of the identity of the recipient of funds would not suffice for the offense, as it would include both guilty and non-guilty mental states into the scope of liability. It also imposes liability on well-intentioned financers who seek to provide resources to non-violent humanitarian and political activities of a group. Multiple legal challenges would also target any higher intent requirements (recklessness or specific intent), including arguments based on vagueness, overbreadth, and the requirement of the presumption of innocence. This is because, in the absence of commission of any terrorist act, a financer should have "terrorist purposes"; but the term "terrorist purposes" has not been defined. It has been argued that the application of terrorist purposes as a mental requirement could result in the creation of a whole new class of political crimes. 